\title{
Flexible Supply of Apprenticeship in the British Industrial Revolution
}

\author{
Nadav Ben Zeev, Joel Mokyr, and Karine van der Beek
}

\begin{abstract}
We use annual information on apprenticeships in England between 1710-1805 to estimate the dynamic supply-responsiveness in this market in the presence of the increasingly powerful technological shocks as the Industrial Revolution proceeded apace. Using both an Instrumental Variable method and a dynamic Vector Autoregression framework (VAR) system to identify the long-run response functions, we find evidence of an elastic supply, sufficiently high as to allow quantities to rise considerably in response to demand shocks. This finding lends support to the view that Britain's apprenticeship institution was the source of its advantage in skilled mechanical labor, so critical to its economic success.
\end{abstract}

$\mathrm{T}$ he attempt to explain the timing and location of the British Industrial Revolution has attracted many controversies among economic historians (Mokyr 1999; Allen 2009). The issue of British leadership over Continental countries has been of special interest and has focused on institutions, resources, colonial advantage, and culture. ${ }^{1}$ Among the numerous explanations, the role of human capital and its relationship with technological change has received growing attention in the last decade, much due to developments in economic growth models. The role of human capital in many recent growth models is a central one (e.g., Galor 2011; Glaeser et al. 2004). These models usually assume the existence of a dynamic relationship between technological change and human capital in which human capital both advances technological change and results from it because of an increase in the demand of employers for skilled workers, needed to implement and maintain the new technologies. In

The Journal of Economic History, Vol. 77, No. 1 (March 2017). (C) The Economic History Association. All rights reserved. doi: 10.1017/S0022050717000043

Nadav Ben Zeev is Assistant Professor, Department of Economics, Ben Gurion University, P.O. Box 653, Beer-Sheva 84105, Israel. E-mail: nadavbz@bgu.ac.il. Joel Mokyr is Professor, Northwestern University, Tel Aviv University and CIFAR, Department of Economics, Northwestern University, 2001 Sheridan Road, Evanston, IL 60208, USA. E-mail: j-mokyr@ northwestern.edu. Karine van der Beek, Senior Lecturer, Department of Economics, Ben Gurion University, P.O. Box 653, Beer-Sheva 84105, Israel. E-mail: kvdbeek@bgu.ac.il.

This research was funded by the Binational Science Foundation Grant \#2010081 for which we are deeply grateful. The excellent research assistance of Mor Uzan is acknowledged. The very helpful comments of the editor of this JoURNAL and three referees are gratefully acknowledged, as are the suggestions and support of Patrick Wallis. We also acknowledge with gratitude the suggestions of Maarten Prak and Bert De Munck. All remaining errors are our responsibility.

${ }^{1}$ For surveys see especially Clark (2007), Mokyr (2009), and McCloskey (2010). 
the current study we focus on the supply side of human capital and its response to changes in demand in the British Industrial Revolution.

For technological progress to take place, a corresponding increase in the supply of skilled practitioners is required to keep pace with the demand for highly trained workers (Ryoo and Rosen 2004). What we show in this article is that Britain's system of apprenticeship, which was the formal system for acquiring skill, was highly flexible and effective, allowing mobility between skills and did not seem to create significant institutional barriers to most of the manufacturing trades. Given Britain's reputation for the mechanical skills of its workmen during the eighteenth century and their important role in Britain's industrialization, our results suggest that this feature was/may have been one of its most significant sources of advantage in becoming "the cradle of the Industrial Revolution," as pointed out by Jane Humphries (2003) and Morgan Kelly, Joel Mokyr, and Cormac Ó Gráda (2014). Our findings also support the argument made in Mokyr (2008) that the institutional advantage that provided the British economy with an edge for the Industrial Revolution was the agility in which its economic institutions adapted to changes in the environment.

The supply responsiveness in markets for human capital is not a minor matter even in modern economies. Concerns regarding the capability of markets in supplying the U.S. economy with the necessary skilled personnel have been expressed since the 1950s, when a shortage of scientists and engineers was said to have occurred in the United States. More recently, in the 1990s, many policy makers were alarmed by the decline in the engineering share of college freshman enrollment (which was as high as 10 percent in the early 1980s but has declined steadily since then to 7.4 percent in 1999). Jaewoo Ryoo and Sherwin Rosen (2004) addressed these concerns by examining the engineering labor market, showing that it responds strongly to economic forces. They found a high elasticity of supply of engineering students to economic prospects and a rapid response to changing conditions.

In this article we show that the supply of apprentices in eighteenthcentury England was highly responsive as well. We use annual information from the Stamp Tax registers on apprentices in England between 1710-1805 to examine the response of the tuition fees paid by the families of apprentices to changes in the annual number of apprentices in different trades and find that its standard supply elasticity was high in the sense that the tuition increased only slightly $(0.15-0.2$ percent) in response to a percentage increase in the number of apprentices and that tuitions rose in the short run while returning to their equilibrium level in 
the long run. ${ }^{2}$ This implies that the apprenticeship system could absorb the significant demand shocks in the market for apprenticeship in this period, as was the case with many of the highly skilled mechanical trades, and supply the skilled workers required to accommodate technological changes. ${ }^{3}$ Furthermore, we find that this elasticity was stable throughout the century and that it was characteristic of the system as a whole and not particular to specific trades. Our findings complement those of Tim Leunig, Chris Minns, and Patrick Wallis (2011) who conclude that at least in London the market for apprenticeships was fluid, open, accessible, and flexible.

Although our finding of elastic supply of the production of skills is not by itself a demonstration of British technical advantage, and alternative interpretations could be suggested, including an elastic supply of labor but at a low level of skill, it is consistent with other evidence that suggests that Britain's supply of skills was not just elastic but existed at a high level. Contemporary observers, British as well as foreign, commented on the high quality of English workmen (Mokyr 2009, pp. 106-8). Moreover, from the middle of the eighteenth century to the middle of the nineteenth English and Scottish mechanics and skilled craftsmen were eagerly sought after by Continental governments and industrialists, to install, maintain, and operate the complex equipment used in mechanized manufacturing (Kelly, Mokyr, and Ó Gráda 2014). The mercantilist tendency to "protect" what was seen as a mobile source of comparative advantage is reflected in the notorious laws prohibiting the migration of skilled artisans (the first one dated from 1695). We argue that Britain's high level of skills was made possible because its apprenticeship system easily adapted to changes in the composition of demand for skills, and, as we show here, was not characterized by significant entry barriers to most of the manufacturing trades.

Two different methods are employed in our analysis. We first employ a two stage instrumental variable procedure to estimate a static market system. Since the tuition and the number of apprentices are observed in equilibrium and are simultaneously determined, the elasticities cannot be consistently estimated using ordinary least squares (OLS). To overcome this problem, we make use of the fact that short-run fluctuations in aggregate death rates were largely driven by the changes in the death rates of young children to instrument for changes in the demand side in the market for apprentice positions. We also use the population of children aged 15 to 24 as an additional instrumental variable.

\footnotetext{
${ }^{2}$ The registers are kept at the National Archives, Kew, under Series IR 1.

${ }^{3}$ Feldman and van der Beek (2016) have shown the strong response of this occupational category to technological changes.
} 
Since the system is in fact a dynamic one and the capability of masters to respond to rising demand for apprentice positions clearly increased, we move from estimating a Marshallian short-run to a long-run response. We therefore also employ a Vector Autoregression framework (VAR) to test the short-run and long-run response of both the number of apprentices and the tuition to technological changes in the aggregate level, as well as in specific occupational categories. The VAR analysis has the additional advantage of allowing us to examine the effect of technological shocks accounting for the dynamic interaction between the variables since it involves jointly regressing all variables on their own lags. This analysis shows that both quantities and tuitions responded in a hump-shaped manner to technological shocks, increasing in response to the shock and gradually returning to their initial level in the long run. The implied elasticities of tuition, computed as the ratio of the tuition response to the quantity response show that the elasticity of prices was sufficiently low so as to allow for quantities to rise considerably following the technology shock. It is important to note that given that more than 90 percent of the masters in the data had only one apprentice over their lifetime, this responsiveness seems to have been primarily at the extensive margin (more masters taking up apprentices) rather than at the intensive margin (more apprentices per master); however this remains to be tested in further research. ${ }^{4}$

There are several studies that examine the role of human capital in context of the Industrial Revolution since the seminal work of David Mitch $(1999,2004)$ and Lars G. Sandberg (1979) showed the relative unimportance of traditionally measured human capital (i.e., formal schooling and literacy). ${ }^{5}$ The main conclusions that may be drawn from these studies are, (1) that the system of apprenticeship, which was once regarded as a tool used by craft guilds to exclude competition, was responsive to market forces, contributed to innovations and to labor mobility (Epstein 1998; Humphries 2003, 2010; Justman and van der Beek 2014; Mokyr 2009; Wallis 2008) and (2) studies show that there was a significant increase in the number of highly skilled mechanical apprentices during the eighteenth century, a category of occupations shown to be the relevant one for technological change (Mokyr 2009; Meisenzahl and Mokyr 2011; van der Beek 2014; Feldman and van der Beek 2016). This article sheds light on the remaining question, which is whether the system of apprenticeship was "effective" and finds it to be indeed responsive to shocks, with the

\footnotetext{
${ }^{4}$ In other words, about 90 percent of the masters appear only once in the data, (taking into account only masters that appear until 1770 assuming 35 years in which masters could potentially take an apprentice).

${ }^{5}$ More recent work, such as Becker, Hornung, and Woessmann (2011), has confirmed the role of formal education in the technological catch-up of following economies, but has not weakened the original insights by Mitch on the relative unimportance of formal schooling.
} 
prices (i.e., tuition fees) paid for the apprenticeship gradually returning to their initial level in the long run.

\section{THE FLEXIBILITY OF BRITISH APPRENTICESHIP}

The important economic contribution of apprenticeship to innovation and to labor mobility has been highlighted over the last two decades (Epstein 1998; Mokyr 2009; Humphries 2003, 2010; Wallis 2008; Van Zanden 2009, Ch. 5). Another literature has focused on many of the more detailed aspects of apprenticeship, emphasizing its importance in the intergenerational transmission of knowledge that was primarily tacit in nature (De Munck 2010, 2011; Davids 2007; Epstein 2013).

The institution of apprenticeship was, of course, not particular to Britain. However, there is reason to believe that it developed into a more flexible and responsive system there than elsewhere. By the eighteenth century Britain had access to a work force of highly skilled artisans that dwarfed anything that other European countries could amass. What happened on the Continent is more complex. Clearly in many areas guilds established the rules of apprenticeship and supervised the actual training (Crowston 2007, p. 46). Yet the contract was notarized (by royal edict of 1691) and as Steven L. Kaplan (1993, p. 437) has pointed out, it involved not just the master and the pupil but also the community (i.e., the guild), the government (at various levels), and the potential customers. Nicole Pellegrin-Postel's (1987, pp. 269-70, 275, 284) detailed analysis of the notarial apprenticeship contracts in the Haut-Poitou area shows that in many cases some of the provisions of the contracts were ignored and that there was a great deal of variability in the duration and other terms of the contract. At the same time there was very little geographical mobility among the apprentice population and it was common for apprentices to choose a trade that was close to that of their father.

The evidence that eighteenth-century French guilds stood in the way of technical progress has been increasingly questioned, and their power to monopolize production was much weakened by the existence of guild-free regions such as the famous Faubourg Saint-Antoine near Paris. Although the guilds survived Turgot's famous but ill-fated attempt to suppress them in 1776, their recovery was slow and gradual (Fitzsimmons 2010, pp. 14-15). All the same, despite cracks and weaknesses, Fitzsimmons (2010, p. 10) concludes that they were still a permanent fixture in French society and that as late as 1750 there was little to indicate their imminent demise. In most places guilds created a relatively rigid institutional framework of rules that stood in contrast to the more agile British 
system (Ogilvie 2014). ${ }^{6}$ Robert Darnton's (1984, pp. 114-15) famous observation about mid-eighteenth-century Montpellier-that it was no Manchester, that it produced the same goods on the same scale, and that its journeymen and masters went about their business pretty much in the same way as they had two hundred years earlier - may not be true for the more advanced regions of France. But it is perhaps telling that when the Englishman John Holker was asked by the French government to set up a textile factory in Normandy in 1752, he had to depend on 20 English artisans and mechanics, who were allocated among French workers such that their skills could be disseminated in the most effective fashion among the local workers (Henderson 1954, p. 16; John R. Harris 1998, p. 60). With the demise of the French guilds after the revolution, the institutions of apprenticeship in France fell on hard times and attempts to restore it in the nineteenth century "were strangely out of step with economic reality" (Lequin 1986, p. 463). This stood in contrast with Britain, where, despite the abolition of the Statute of Artificers in 1814, apprenticeship was alive and well in the nineteenth century (Elbaum 1989). ${ }^{7}$

Three elements were responsible for the flexibility in Britain that allowed it to "produce" large amounts of artisanal human capital. First, by the eighteenth century the guilds in Britain had been weakened and their regulatory powers were limited and further undermined during the civil wars (Epstein 1998, pp. 686-98; Berlin 2008). Of course London and the "old towns" still had guilds (or companies, as they were known), but precisely because so much of the country was guild-free, it became almost impossible to use the guild system to regulate and limit entry into any occupation and maintain exclusionary rents. ${ }^{8}$ The London guilds simply no longer had the power to regulate key occupations, including the flows of new workers into them. ${ }^{9}$ Second, the strictures of the Statute of

\footnotetext{
${ }^{6}$ One indication to the rigidity of the standard apprentice system in France is the emergence of a parallel track known as alloué (or assigned) to evade the strictures of formal apprenticeship, although Kaplan (1993, pp. 459-64) concludes that in practice there was little difference between the two systems. A similar distinction métiers jurés (sworn trades) and métier libres (free trades) is made by Pellegrin-Postel (1987) who draws a similar conclusion.

${ }^{7}$ The country which most resembled Britain as far as its institutions of apprenticeship are concerned is the Netherlands, where guild control was weak but apprenticeship contracts survived (Davids 2007). Even there, however, a need was felt for British advice and technological expertise in the nineteenth century.

${ }^{8}$ Wallis $(2008$, p. 851) has concluded that London guilds did not have much to do with the enforcement of apprenticeship contracts by the late seventeenth century, and yet the institution nevertheless "thrived."

${ }^{9}$ For instance, Ogilvie (2014, p. 185) points to the fact that the London "livery companies" of the clockmakers and spectacle-makers (a crucial part of the high-tech artisanal sector) no longer regulated entry, facilitating an influx of venturesome newcomers and innovative methods from adjacent occupations; by contrast, in France, the industry was still stifled by guild regulations. To be sure, some London companies such as Pewterers and Goldsmiths had some privileges that allowed them to enforce quality standards on the country as a whole, but their behavior shows that even the guilds in London were capable of adapting to continuously changing circumstances (Gadd and Wallis 2008).
} 
Artificers were not strictly enforced so that the length of contract became a decision variable. Humphries (2010, pp. 268-69) recognizes this flexibility and notes that the contracts could be customized and adapted to particular cases. Finally, eighteenth-century Britain experienced a flourishing of a high degree of social capital, meriting the moniker of an "associational society" (Clark 2000). This social capital supported a reputational mechanism that kept both apprentice and master from engaging in excessive opportunistic behavior (Mokyr 2008). The decision to pick a particular master was often driven by family interests made by the family as a whole, and the fairly low incidence of young lads being apprenticed to their own fathers suggests a high level of trust between the two parties, which reduced, but did not entirely eliminate, uncertainty and the chance for opportunistic behavior on either side, (Humphries 2010, pp. 270-71).

What was unique in England was that the institution of apprenticeship was regulated by the central government yet these regulations may well have worked in England's favor. The Statute of Artificers (1563) added formal legal regulation of apprenticeship to the customs and rules of the guilds extending the guild practices of the City of London and other corporate towns to urban England, including the seven-year term of service. The Statute did, however, contain some interesting deviations from guild regulations. For example, a legally completed apprenticeship gave a young man the right to practice his trade without distinction of place, that is, he was not required to work and trade in the same place where the term of apprenticeship had been served. According to Humphries (2003, p. 96), "this aspect of the Statute, which distinguished it from continental legislation, perhaps recognized that industrial skills had ceased to be a prerogative of the town craftsman and become a characteristic of the intermingled agricultural-industrial life of the countryside." By making it possible to hire workers outside their city of residence, the Act effectively left masters at liberty to employ as many apprentices as their work demanded (Dunlop 1911, p. 207; Epstein 1998, p. 689).

The question is whether the clauses of the Statute were indeed enforced, and if so, which of the clauses. Various studies have shown the enforcement of the Statute of Artificers to be incomplete. According to Ron Harris (2004, p. 208), incomplete enforcement was a result of the lack of updating and maintenance of the regulations by parliament and as a result "The Statute of Artificers and its offspring became increasingly detached from reality as time went on. This was not a problem of enforcement. Parliament needed to invest time and effort in drafting the regulation in a manner that would be sufficiently detailed and would address the complexities and variety of contexts of real life. It took maintenance work to keep the regulation current. The British parliament often 
did not do this." O. Jocelyn Dunlop (1911, p. 201) has pointed to the lack of enforcement "machinery" claiming that no officers were especially appointed for the enforcement of the Act and that it was beyond the powers of the common informers. ${ }^{10}$ Notwithstanding the Act, men who had not been regularly apprenticed, but had been merely taught by their fathers, claimed and received admittance to the guilds; the custom of patrimony was preserved everywhere, and it was ranked with apprenticeship as entitling a man to the freedom of his trade association in the ordinances of the guilds. Moreover, Wallis (2008) has shown that the legal stricture to serve for seven years was rarely observed and that workers left when they felt that the gains from staying longer were less than the opportunity costs. To summarize then, while the Statute of Artificers at first blush may seem a source of rigidity, its practical enforcement on the ground was sufficiently flexible to allow a relatively rapid adaptation to changing economic circumstances.

Apprenticeship was thus a formal method of vocational training in crafts and trade that originated in the guild system of medieval times. Ideally, a master or mistress agreed to train a child in a trade for a specific term of years and in most cases to board and house the child. In return the master was paid an agreed premium and the child committed to serve faithfully and keep the secrets of the trade. ${ }^{11}$ The premium paid, served more than one purpose. In part, it was to ensure the master against an early departure of the apprentice. But in part it reflected the quality of the training and the cost to the master, as well as its scarcity value (Minns and Wallis 2013, p. 340). The demand side, they show, did not just reflect the increased productivity that apprenticeship conveyed, but also exclusionary rents (Minns and Wallis 2013, p. 348). "Training premiums," they write, "were used to address the core tensions in securing pre-industrial training contracts." This view is consistent with our notion that it is the observed equilibrium price (tuition) in a market in which the masters are the supply side and the apprentices are the demand.

Another important advantage of the British apprenticeship system was its reputational mechanisms that kept both apprentice and master from

\footnotetext{
${ }^{10}$ Dunlop argued that at first the guilds were in fact the only authorities capable of undertaking the administration of such an act, and indeed, after several years of constant complaints as to the lack of administration, guilds became more active and the Statute began to be more closely enforced in the late sixteenth century. Yet the striking feature of the decades after 1650, she observes elsewhere, was the "increasing disregard for the Statute of Artificers" which in her view was caused by the lack of support from the central and municipal governments and the active opposition of the courts of law (Dunlop 1912, p. 132).

${ }^{11}$ Not all apprentices paid a positive premium, yet they did pay for their training by providing the master with the value of their labor during the apprenticeship term. Thus, this can be viewed as cases where the present value of their work for the master was roughly equal to the teaching costs incurred by the master.
} 
engaging in excessive opportunistic behavior. Apprenticeship contracts by definition were poorly specified, and much was left open to the discretion of the participants. What made this a self-enforcing contract, in which opportunistic behavior was kept at a minimum, was above all the reputation of both participants, even though they were both operating in the shadow of the law and that legal recourse was possible even if it was highly undesirable and expensive (Humphries 2004; Mokyr 2009). The knowledge transmitted between master and apprentice was largely tacit in the sense that the learning took place through observation, absorption, and imitation rather than through direct and full instruction. As Bert De Munck, Steven L. Kaplan, and Hugo Soly (2007, pp. 14-15) put it, apprentices on the shop floor had to "steal with their eyes." Didactic skills were probably of secondary importance and yet the existence of considerable fees that British masters charged for their services suggests that there were incentives for them to build reputations by exerting efforts and spending resources to better instruct their apprentices. ${ }^{12}$

The fee paid to masters was thus dependent on the master's reputation and this placed limits on the degree of opportunism that masters could engage in (Epstein 2013, p. 29). The voluntary termination of so many apprenticeships can be interpreted to mean that at some point the marginal value of the flows between apprentice and master were more or less equal for both and beyond that, neither had much to gain from its continuation. The exact time at which the marginal costs began to exceed the marginal benefits would differ for master and apprentice, and so there was room for negotiation. But precisely because of the self-enforcing institutions of the associational society that made cooperation possible, such differences rarely led to outright conflicts.

In other ways, too, the system was well-designed. In principle, the indenture contract guaranteed that the apprentice would make up the difference between the cost of training and the fee by working as a journeyman or servant to his master after the training was complete. In practice, Wallis (2008) has shown that the traditional view, that the cost to the master and the benefit to the apprentice were heavily concentrated in the first years, may not be the way the institution actually worked by the eighteenth century. He argues persuasively that the flows of costs and benefits to both parties were spaced fairly evenly over the period of the apprenticeship. This is not to say that they were equal: a fee was paid up-front because there was a difference between the present value of the

\footnotetext{
${ }^{12}$ In addition, the training itself must have cost more than just the time of the master: if much of the learning took the form of on the spot learning by doing, with the master "merely expected to point out what had gone wrong," then there would be a substantial cost in terms of spoiled and wasted materials (De Munck, Kaplan, and Soly 2007, p. 16).
} 
net costs and benefits of both master and apprentice, and this fee can be interpreted as the net price of the service delivered in a well-functioning market. But it does imply that the fact that many apprenticeships terminated before the legally mandated seven years is evidence for a flexible and mutually advantageous transaction between master and apprentice.

To sum up: the British apprenticeship system worked, and it worked so well that long after the abolition of the Statute in 1814, the institution remained the central mechanism through which Britain trained its skilled craftsmen (Elbaum 1989; Elbaum and Singh 1995). It seems highly plausible that Britain's advantage in highly skilled craftsmen was in large part derived from a more effective training system.

\section{THEORETICAL FRAMEWORK}

In what follows, we lay out a deterministic, dynamic partial equilibrium model that can establish a valuable conceptual framework upon which to build the discussion and interpretation of our empirical results in the next section. Notwithstanding the model's simplicity, it will prove instrumental in facilitating our understanding of what we mean by efficiency in the apprenticeship market and the implications this efficiency can have on equilibrium outcomes. We begin the presentation of our model with the supply side of the apprenticeship market, followed by an explanation of its demand side, and we close it by defining and discussing the market equilibrium of the model.

\section{Supply Side}

To keep things as simple as possible, we assume there is a representative master. Let us assume the master maximizes the present value of his infinite stream of future profits. The master's revenues are generated by selling apprenticeship contracts, $y_{t}$, produced with capital input, $k_{t}$, using the production technology $y_{t}=f\left(k_{t}\right)$. It is assumed that $f$ is continuously differentiable, strictly increasing, strictly concave, and obeys the Inada conditions, $f^{\prime}(0)=0, \lim _{k_{t} \rightarrow 0} f^{\prime}\left(k_{t}\right)=\infty$ and, $\lim _{k_{t} \rightarrow \infty} f^{\prime}\left(k_{t}\right)=0$. We abstract here from any other activities the master may be undertaking and focus on his activities as an instructor.

The price of an apprenticeship contract is denoted by $p_{t}$; this price is essentially the tuition paid for undertaking the apprenticeship. The master's cost $C$, is the total cost of investment, which we assume is a function of gross investment, $\left[k_{t+1}-(1-\delta) k_{t}\right]$, where $0<\delta<1$ is the capital depreciation rate. Adding variable labor to this model would not change the main takeaway of this section but would complicate the 
exposition; hence, we abstract from this aspect in our model. We make the standard assumption that $C$ is strictly increasing, strictly convex, and differentiable, with $C(0)=0$. These capital costs are incurred because much of the training costs consisted of materials and equipment. Sven Steffens (2001, pp. 124-25), for example, notes that in Belgium little actual direct instruction was done; the apprentice simply was allowed to try and imitate what the master and more advanced apprentices were doing. In the process, he was likely to waste raw materials and fuel, and may have used up equipment and tools. He also occupied space that had an opportunity costs. Moreover, the master and his apprentice had to establish a rapport, and at first an inexperienced apprentice may have disrupted the normal productive activities in the shop. Note that assuming adjustment costs essentially introduces a capacity constraint on the master and is necessary for facilitating a formal dynamic framework in which the master gradually responds to shocks before moving to new steady state rather than instantaneously reaching it. We can now turn to write the maximization problem facing the master:

$$
\max _{\left\{k_{t+1}\right\}_{t=0}^{\infty}} \sum_{t=0}^{\infty} \beta^{t}\left(p_{t} f\left(k_{t}\right)-c\left(k_{t+1}-(1-\delta) k_{t}\right)\right)
$$

where

$$
\text { s.t } \quad k_{t+1} \geq 0, k_{0}>0
$$

$0<\beta<1$ is the master's subjective discount factor. Note that since $k_{t}$ is a state variable that is predetermined with respect to period $t, k_{0}$ is not a choice variable in the master's maximization problem. It is useful to write down the Bellman equation corresponding to the master's problem:

$$
V\left(k_{t}, p_{t}\right)=\max _{k_{t+1}}\left[p_{t} f\left(k_{t}\right)-c\left(k_{t+1}-(1-\delta) k_{t}\right)+\beta V\left(k_{t+1}, p_{t+1}\right)\right]
$$

where

$$
V\left(k_{t}, p_{t}\right)=\max _{\left\{k_{t+1}\right\}_{t=0}^{\infty}} \sum_{t=0}^{\infty} \beta^{t}\left(p_{t} f\left(k_{t}\right)-c\left(k_{t+1}-(1-\delta) k_{t}\right)\right)
$$

It is straightforward to apply to our setting standard dynamic programming techniques and obtain the following standard results: (1) uniqueness of the solution; (2) continuity of $V(k, p)$ and the optimal policy function $k_{t+1}=g\left(k_{t}, p_{t}\right)$; and (3) $V$ is increasing in $k$ and the optimal level of next period's capital is increasing in the level of the current period's capital. ${ }^{13}$

\footnotetext{
${ }^{13}$ For details of how to prove these results, the reader is referred to the solution to Exercise $5.9 \mathrm{~b}$ of Stokey and Lucas (1989) which appears in its solutions manual put together by Irigoyen, Rossi-Hansberg, and Wright (2009).
} 
Combining the first order condition and envelope condition of Equation 2, we can obtain the following Euler equation characterizing the solution to the master's problem:

$$
c^{\prime}\left(k_{t+1}-(1-\delta) k_{t}\right)=\beta\left(p_{t+1} f^{\prime}\left(k_{t+1}\right)+(1-\delta) c^{\prime}\left(k_{t+2}-(1-\delta) k_{t+1}\right)\right)
$$

Equation (3) essentially equates the marginal cost (LHS) and marginal revenue (RHS) of using an additional unit of capital. The master's supply of apprenticeship contracts is implicitly determined by this equation and can be shown to be increasing in the price of the contract. ${ }^{14}$ We can therefore conclude that the solution to the master's dynamic maximization problem generates an upward sloping supply curve.

Given the dynamic nature of the master's problem, it is of interest to ascertain whether there exists a unique and globally stable steady state level of capital. Towards this end, let us write Equation (3) in steady state form in which $k_{t}=k_{t+1}=\bar{k}$, and, $p_{t}=p_{t+1}=\bar{p}$ :

$$
(1-\beta(1-\delta)) C^{\prime}(\delta \bar{k})=\beta \bar{p} f^{\prime}(\bar{k})
$$

Given the strict concavity of $f$ and strict convexity of $C$, and the Inada conditions imposed on $f$, it is straightforward to show that there is a unique and globally stable steady state level of capital. The reason for this is that under these assumptions the term, $(1-\beta(1-\delta)) C^{\prime}(\delta \bar{k})-\beta \bar{p} f^{\prime}(\bar{k})$, takes on a value for a unique value of $\bar{k}$ and this unique steady state is independent of the initial value of capital. Furthermore, it is apparent from Equation (4) that the steady state capital stock is increasing in the steady state price level $\bar{p} \cdot{ }^{15}$ This result and the previous one on the upward slope of the supply curve give us an indication of what will take place following a permanent rise in demand: initially, given that capital is predetermined, capital will not change, but in the subsequent period capital will rise and will continue to gradually rise thereafter until reaching the higher steady state. Importantly, given the capacity constraint facing the master, this new steady state will be characterized by a price level that is lower than that which prevails in the short run. What this means is the apprenticeship supply follows a classical Marshallian pattern: a demand shock drives up the price in the short run, but as adjustment occurs the supply curve becomes more elastic and the adjustment takes place in the quantity space.

\footnotetext{
${ }^{14}$ The proof is by contradiction. Specifically, let us assume that an increase in $p_{t+l}$ does not lead to an increase in $k_{t+1}$ and hence $y_{t+1}$; this implies that the LHS of Equation (3) does not increase, whereas the RHS does increase due to the strict concavity of $f$ thus leading to a contradiction.

${ }^{15}$ This can be proved in an analogous manner to the dynamic case: assuming that an increase in $\bar{p}$ does not raise $\bar{k}$ implies that the LHS of Equation (4) does not increase, whereas its RHS does rise, thus leading to a contradiction.
} 


\section{Demand Side}

Prospective apprentices, indexed by $i$ are assumed to derive economic value from undertaking the apprenticeship, which we denote by $v_{i, t}{ }^{16}$ This variable represents the additional utility gained by the acquisition of a skilled trade. This utility could be seen as the present value of the expected markup in income over the wage of an unskilled worker, the higher social status of a skilled artisan, and possibly the pride and satisfaction of producing more sophisticated goods. This additional utility is explicitly defined as:

$$
v_{i, t}=\sum_{j=0}^{\infty} \beta^{j} \omega_{i, t+j}
$$

where, $0<\beta<1$ is the prospective apprentice's subjective discount factor, which we assume for simplicity to be equal to that of the master's, and $\omega_{i, t}$ is the expected payoff at period $t$ from undertaking the apprenticeship. One reason for the assumed heterogeneity in $v_{i, t}$ across different apprentices is that different prospective apprentices are likely to possess different levels of talents. Given that the decision taken by the prospective apprentice is a binary one, we define a binary variable $x_{i, t}$ that takes the value of one if the apprenticeship is decided to be pursued and zero if it is forgone by the prospective apprentice. Moreover, since the cost of taking part in the apprenticeship is $p_{t}$, the apprentice's net payoff function is $v_{i, t}-p_{t}$ if the apprenticeship is pursued and zero if it is foregone. ${ }^{17}$ Therefore, we can describe the solution to the prospective apprentice's problem simply as follows:

$$
\left\{\begin{array}{lll}
x_{i, t}=1 & \text { if } & v_{i, t}-p_{t} \geq 0 \\
x_{i, t}=0 & \text { if } & v_{i, t}-p_{t}<0
\end{array}\right.
$$

\section{Equilibrium}

For the purpose of defining the market equilibrium, let us first assume there is a total number of $N$ masters each offering $y_{t}$ contracts so that the

\footnotetext{
${ }^{16}$ Given the very young age of apprentices in our sample period, one can view the prospective apprentice as the legal guardians of the apprentice.

${ }^{17}$ It is worth noting that the cost to the apprentice is not just the tuition fee but also the annual opportunity cost of his time; nevertheless, we abstract from this by normalizing this opportunity cost to zero.
} 
total number of offered apprenticeships is $\mathrm{Ny}_{t}{ }^{18}$ Market equilibrium will take place when aggregate supply of apprenticeships equals the aggregate demand for apprenticeships, that is, $N y_{t}=\sum_{i} x_{i, t}$. For a sufficiently large number of prospective apprentices as well as a sufficiently large level of heterogeneity as manifested in the variation in $v_{i}, \sum_{i} x_{i, t}$, would be a standard downward-sloping demand curve; the simple reason for this is that, under these conditions, raising the tuition level would drive at least one prospective apprentice out of the market.

Note that in this setting shifts in the aggregate demand for apprenticeships are caused by variation in the value of $v_{i, t}$. The main potential economic demand shifter is technological changes in the relevant sector; for example, technological improvements raise the expected earnings from the specific trade thus raising demand. It is important to stress that the actual diffusion of the innovation (which may take years) is less relevant than the knowledge of the new technique has arrived. Informed people will anticipate its diffusion and thus adjust their demand for apprenticeship accordingly. Another possible demand shifter is health; for instance, deterioration in the health of prospective apprentices is likely to reduce their expected earnings (and a shortening of the period in which they have higher earnings) and as a result cause a decrease in the demand for apprenticeships.

The equilibrium of this Marshallian model is conveniently depicted by Figure $1 .{ }^{19}$ Let us assume the initial position of the market is some steady state (point A). Technological change will normally cause the demand curve for skills to shift to the right. ${ }^{20}$ Since there is no change initially in the level of apprenticeship contracts given that capital is predetermined (that is, capacity is constrained), we will move to point B.

In the following period the new equilibrium will be to the right of the initial one reflecting both a higher tuition level as well as a higher quantity of apprenticeships, putting the market equilibrium at point $\mathrm{C}$. Subsequently the number of apprenticeship contracts will gradually rise along the new demand curve until reaching the new steady state of

${ }^{18}$ Note that we assume here that all adjustment occurs through masters taking on more apprentices and that $\mathrm{N}$ is exogenous. An interesting extension of the model would be to allow adjustment on the extensive margin as well and allow new masters to enter as instructors.

${ }^{19}$ A conceptually similar graphical depiction appears in Figure 3 of Lucas (1967), which is based on a continuous-time model to which our model is similar.

${ }^{20}$ This is the case if, as seems plausible, technological progress in the early stages of the Industrial Revolution exhibited technology-skill-complementarity. Even if innovation was in some areas on average de-skilling, it still would have required in some sectors different skills, increasing the demand for those skills that were complementary to the new techniques. 


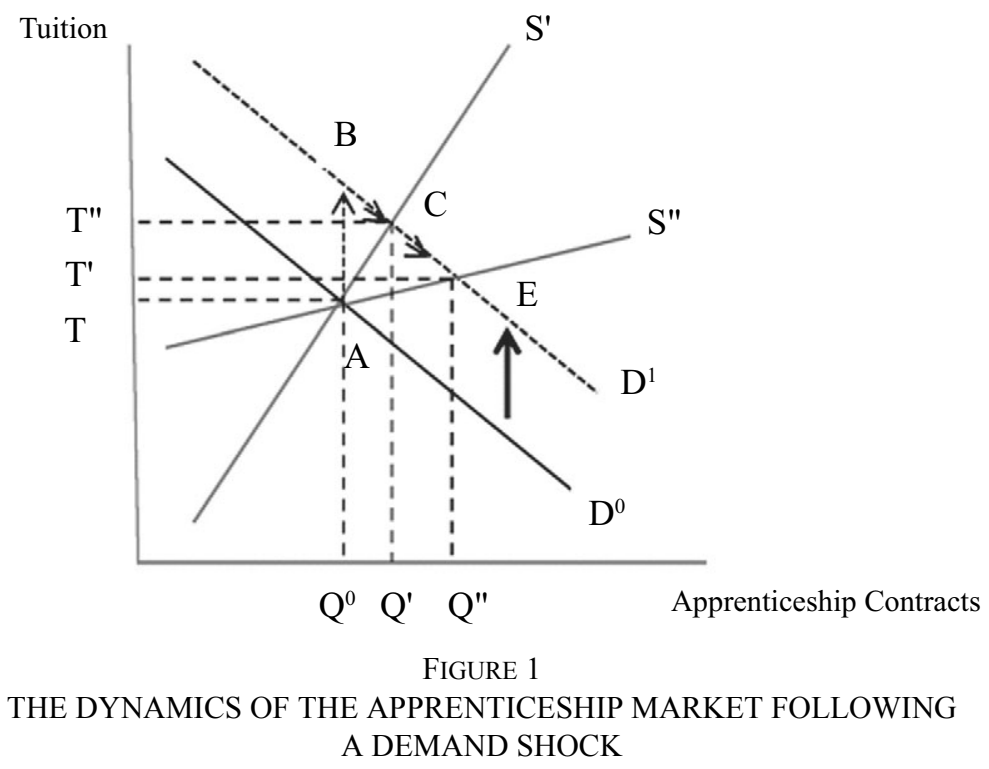

Notes: Curve S' represents the supply curve that corresponds to the subsequent period after the demand shock takes place; $\mathrm{S}$ " is the supply curve that corresponds to the long run. The demand curve shifts rightward from curve D0 to D1. Point A represents the initial steady state, point B is where the equilibrium will be immediately after shock, point $C$ is where the equilibrium will be one period after the shock, and point $\mathrm{E}$ is the new steady state.

Source: Authors' compilation.

point E. The figure demonstrates our notion of efficiency in the context of this shift in demand and movement along the supply curve. A bigger increase in the long-term quantity of apprenticeships was highly important for economic growth. An elastic supply of skills meant not only that the total national "stock" of skilled labor could increase, but that its composition could change relatively rapidly, adapting the distribution of skills to the needs of the changing economy.

\section{EMPIRICAL ANALYSIS}

\section{The Dataset}

The data used in this article come from registers kept by the Board of Stamps of moneys received as stamp duty on apprentices' indentures all over Great Britain, introduced in 1710 and abolished in $1804 .{ }^{21}$ The

\footnotetext{
${ }^{21}$ The last tardy payments continued to trickle in until January 1811 . We dropped observations coming from Ireland, Scotland, and Wales and observations of contracts to masters in agricultural occupations or aristocratic titles, due to the concern that they were not representative of all contracts.
} 
registers consist of: "City" registers (October 1711 to January 1811), with daily entries of the indentures upon which duty was paid in London, and "Country" registers (May 1710 to September 1808) with entries of the indentures upon which duty had been paid to district collectors and which were then sent in condensed batches to be stamped and entered in London. Each entry in the registers contains information on the name of the apprentice, the name of the master to whom he was indentured, the master's trade and place of residence, and the value of the premium paid to the master for taking on the apprentice (i.e., tuitions). ${ }^{22}$

Our dataset consists of all apprenticeship entries from 1710 through 1805 (464,408 entries). ${ }^{23}$ Masters' trades were classified into 78 broadly defined trades after adjusting for minor variations in the spelling of identical occupations of masters in the data, and distinguished by whether the entry is from London or not, in order to account for London's apprenticeship unobserved characteristics. ${ }^{24}$ After we restrict trades to have at least 500 entries over the entire period and years to have at least 1,000 entries for both "City" and "Country" (to more accurately capture population means) and after collapsing the data to the occupational - London/ Country - year level, we remain with an unbalanced panel of 12,429 observations. ${ }^{25}$

\footnotetext{
${ }^{22}$ For an extensive discussion of the possible biases of the source see Feldman and van der Beek (2016). It is important to note that the Stamp Tax entries do not contain those contracts where no premium was paid to the master. Although this seems like an obvious limitation to our analysis, it should not be expected to have any significant qualitative effect on our results. For example, a negative shock to quantities (higher smallpox incidence) would be expected to lower the premiums and consequently increase the percentage of zero-premium contracts. This implies that including these contracts in our dataset would have only increased the elasticity that we observe. Systematic differences in the percentage of zero-premium contracts between occupations should be captured by the fixed effects on occupations that are included in our regressions, assuming that these differences were more or less fixed over time. In addition, the differences in the percentage of zero-premium contracts between occupations in our data are expected to be small given that according to Minns and Wallis (2013): "The probability of paying a premium was higher in occupations where premiums were larger" (p. 343), and that the range of premiums paid in most of the occupations in our analysis was within the high range of 10-25 pounds (besides the services and mercantile trades).

${ }^{23}$ The entries for the years 1710-1772 were kindly provided to us by Chris Minns and Patrick Wallis from the economic history department at LSE. Entries from before 1710 and later than 1805 , and those for which the information was not complete were dropped.

${ }^{24}$ See Appendix Table 1. The professions were aggregated into broader categories based upon Van Leeuwen, Maas, and Miles (2002) HISCO system (Historical International Classification of Occupations), an occupational information system that is both international and historical, and that provides basic information on various trades. HISCO was used as the basis for our classification along with Campbell's (1747) manual, The London Tradesman. A wider classification into 13 occupational groups are also presented in the table and is used only for presentational purpose and not in our regression analysis of which the results are presented in Tables 1a and $1 \mathrm{~b}$.

${ }^{25}$ By these limitations we lose the years 1727, 1733, and 1734. The reason for having less than 13,432 observations is that there are some years in which there were no contracts in all the 73 occupational categories (in either London, Country, or both).
} 
Our main variables of interest are the average annual tuitions and the number of apprentice contracts in each occupational category. To account for other potential determinants of tuitions we combine this dataset with other variables, including, the Consumer Price Index (CPI), the wages of unskilled day laborers and the number of war recruits. ${ }^{26}$ These variables are all constant between occupational groups and only vary between years. They are mainly used to capture relevant changes over time when a year fixed effect cannot be included in the regression.

Finally, our VAR analysis requires a series that captures technological change to identify a technology shock as the VAR innovation in this series. In the absence of standard measures such as annual changes in Total Factor Productivity (TFP) or Research \& Development (R\&D) outlays, we use two alternative measures: the number of inventions relevant to the textile sector, and the total number of patents in England, weighted by their importance. The number of inventions relevant for the textile industry, was constructed by Trevor Griffiths, Philip A. Hunt, and Patrick K. O'Brien (1992), who took into account all the known inventions that had a potential application to textiles, both patented and not. The number of inventions relevant to textile began to grow during the $1730 \mathrm{~s}$ and 1740 s in tandem with the rise in cotton manufacturing, reflecting the intense development activity that was taking place in this sector. Interestingly, the weighted number of patents shows a similar increase during these same years, reflecting the rise in the importance of inventions. These series therefore allow us to capture the effect of the increase in the intensity of development activity. Because of the very proximate nature of any series of inventive activity, it should be emphasized that they are used only in our VAR estimates; the regressions we estimate do not rely on these series. The fact that we get very similar results for both estimation techniques suggests that our findings are robust to objections to the series for inventions.

Since the Griffiths, Hunt, and O'Brien (1992) series exists in increments of five years (e.g., 1710, 1715, 1720, etc.) we fill in the intervening years. As in Naomi E. Feldman and Karine Van der Beek (2016), we take the number of inventions in year $t$ and assume that one-fifth of this number is created each year. Then, we calculate the three-year moving average of inventions. None of the results we present are particularly

\footnotetext{
${ }^{26}$ The CPI is for London from Allen. (2001). The dataset is available at: http://www.nuffield. ox.ac.uk/users/allen/data/labweb.xls; the daily nominal wages of laborers are from Clark (2005, Table A2, p. 1324). The disaggregated data is also available on Clark's personal website at: http:// www.econ.ucdavis.edu/faculty/gclark/data.html; and the number of war recruits are the number of men to be recruited for war from Schwarz (1992), Table 3.3, pp. 97-99. All variables are given annually.
} 
sensitive to this specification. The second variable that we use is the annual number of patents weighted by the Woodcroft's Reference Index (an index constructed by Nuvolari and Tartari 2011) that aims at capturing the significance of a patent by the number of citations it has in the contemporary technical literature. While this series of patents, weighted by their importance, does not fully correct the biases in the patent series, it does allow, to a large extent, to correct some of the downward bias in the number of patents by giving larger weights to the more significant inventions. In addition, it allows us to capture the effect of inventions in general and not only of those relevant for the textile industry. As the VAR analysis shows, the analysis is not sensitive to the use of proxy for technological change and presents similar qualitative results.

\section{Descriptive Statistics}

Summary statistics for the number of apprentices and the tuitions in our various occupations are displayed in Appendix Table 1. As the table shows the average number of new apprentices in every occupation per year were 36.7 and the tuition 27.1 pounds. The number of new apprentices was obviously larger in more common occupations, including for example, house carpenters (174.2), tailors (173.4), shoe-makers (284), bakers (82.6), butchers (95.5), and weavers (99.5) and the tuition was higher in certain occupations with various barriers to entry such as lawyers (108.5 pounds), surgeons (70.7 pounds), merchants ( 75.4 pounds), and brewers (77 pounds).

Feldman and van der Beek (2016) have shown that the number of new apprenticeships increased in response to inventions in the years 1710 1772 , with the strongest increase being in among carpenters and machine making occupations, which were most strongly affected by technological changes. ${ }^{27}$ What we are interested in in this article, is the response of tuitions. Figures 2-3 illustrate the number of new apprenticeships and the level of nominal and real tuitions relative to their level in the years 1710-1720 (in average) in various occupations, grouped by larger occupational categories. The figures indicate that apprenticeship tuition levels remained stable in the long run. Tuitions responded moderately to changes in the annual number of new apprenticeships in the short run but always returned to their equilibrium level. ${ }^{28}$ This feature, which will be

\footnotetext{
${ }^{27}$ Feldman and van der Beek (2016, p. 26). Machine making occupations include trades such as millwrights and wheelwrights, clock makers, compass makers, mathematical instrument makers, etc.

${ }^{28}$ The Napoleonic wars and the economic crisis in the 1790s seem to have interrupted this system with both nominal and real tuitions rising until the end of the period of our study.
} 


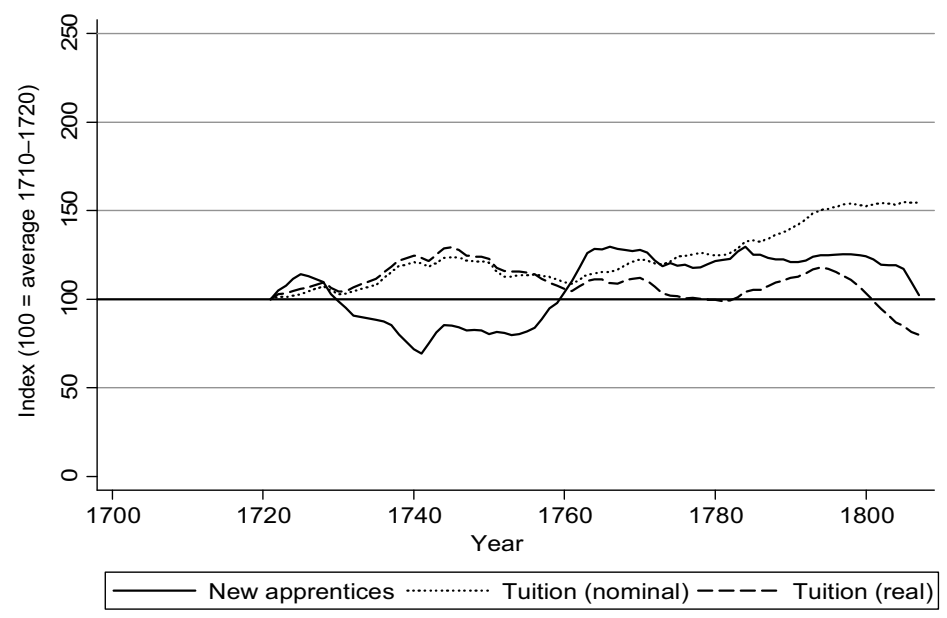

FIGURE 2

AGGREGATE NUMBER OF NEW APPRENTICES AND TUITION LEVELS: 1710-1805

Notes: 10-year moving average.

Source: The Stamp Tax Registers.

shown to be statistically significant in the econometric analysis, suggests a high level of elasticity of the supply side of the apprenticeships system in this period, and was characteristic of almost all the occupations. Figure 2 depicts the changes in the aggregate number of new apprenticeships. As the figure shows, there were no major shocks to the number of apprenticeships at this level as the main changes were in the occupational distribution of apprenticeships rather than on their total number.

As can also be observed in Figure 2, there are some serious drops in the number of entries in the registers, in both series ("City" and "Country"), in the years 1726-1740, and more moderate falls in the years 1745-1751. These falls in the number of entries seem to be partly due to register losses but since they become more frequent in years of high death rates which were mainly caused by bad harvests and smallpox outbreaks as identified by E. A. Wrigley and R. S. Schofield (1981, p. 162), they may also represent a real decrease in the number of apprenticeship contracts. ${ }^{29}$ Since the exact reason for these strong declines in the number of entries is unknown, we concentrated on controlling for the possible effects they may have on our results, dropping years with small numbers of entries and controlling for changes in the composition of entries from "City" and "Country" registers, as will be explained in what follows. We also examine the effect of the drops on our results by estimating our model in periods that are not

\footnotetext{
${ }^{29}$ For more on the connection among death rates, smallpox, and apprenticeship see Feldman and van der Beek (2016, p. 100).
} 


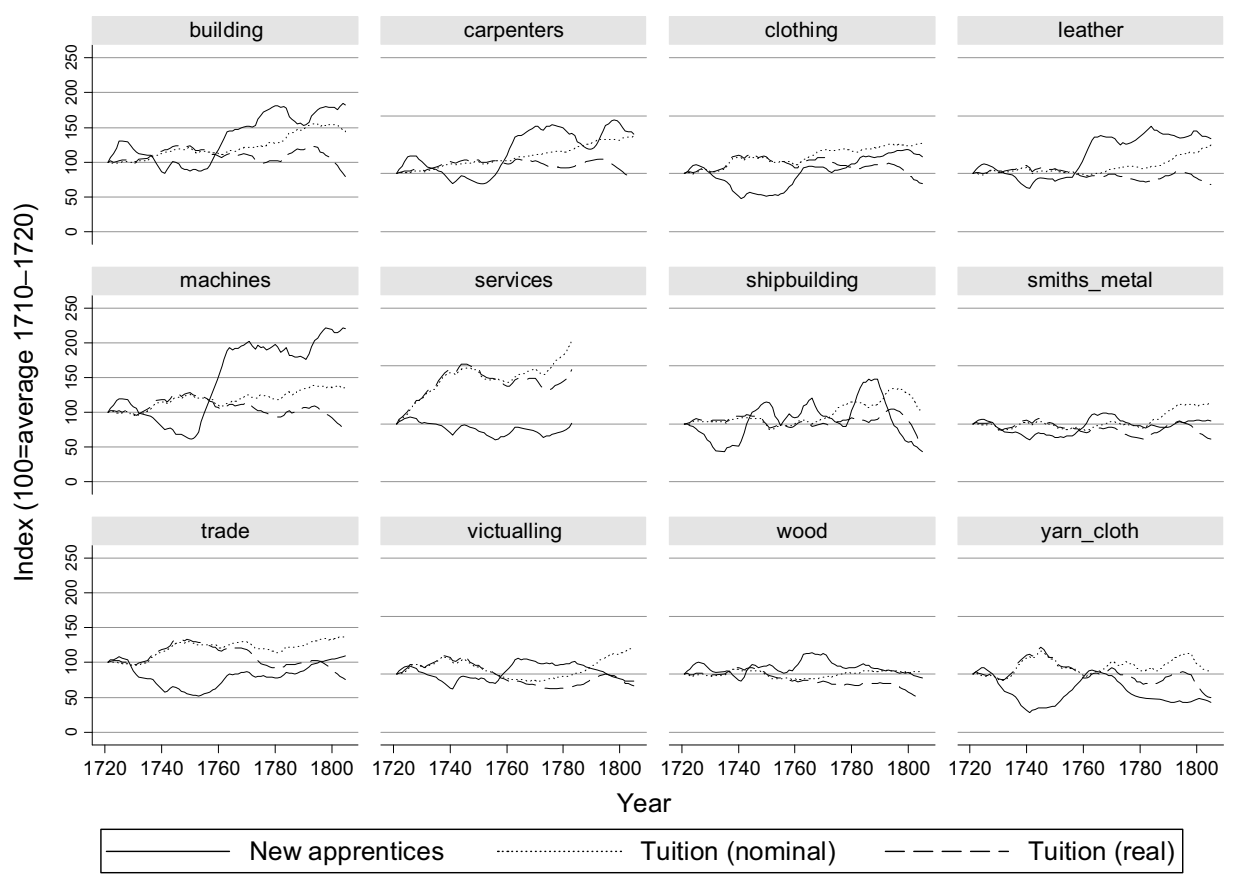

FIGURE 3

NUMBER OF NEW APPRENTICES AND TUITION LEVELS BY OCCUPATION:

1710-1805

Notes: 10-year moving average.

Source: The Stamp Tax Registers.

characterized by such drops in the number of entries (1750-1805) and obtain very similar estimates for the elasticity of supply of apprenticeship. ${ }^{30}$ In addition, we include a variable that measures the ratio of entries from London relative to Country to capture possible effects of changes in the composition of entries that are not constant over time due to drops in the number of entries in one of the series. We also use annual death rates and the log of the population of the 15-24 year olds (the relevant age for apprenticeships) to instrument for the number of apprentices given the simultaneous relationship between this variable and tuitions, as we will be discussing more extensively in the next section. ${ }^{31}$

Figure 3 displays the same variables in various occupational groups. It is clear from this figure that both in occupations in which the number

${ }^{30}$ Table $1 \mathrm{~b}$ column (3).

${ }^{31}$ Annual death rates are from Wrigley and Schofield (1981, Table A3.3, pp. 531-34) (given annually); the annual population of the 15-24 year olds was calculated from the percentage of this group out of the total population given in Wrigley and Schofield (1981, Table A3.1, pp. 528-29). The variable is given for every fifth year and we filled-in the intervening years using a linear trend. 
of new apprenticeships remains almost unchanged and in those in which they increased significantly as in machine making, carpenters, building, and leather production, real tuitions seem to have responded moderately and remain unchanged in the long-run. The number of new apprenticeships in machine making, carpenters, building, and leather production occupations increased by $50-150$ percent in the mid-eighteenth century and yet real tuitions remain stable in the long run. The only case in which we observe a significant and ongoing increase in real tuitions is in the services sector, which includes a very heterogeneous group of occupations including physicians and lawyers, occupations that were changing quite drastically in the eighteenth century.

In the case of apprenticeship in the machine making occupations, the number of new apprenticeships increased by more than 200 percent in the 1750 s while tuitions increased by less than 20 percent and returned to their initial level. Similarly, the number of apprenticeships to carpenters and joiners increased by nearly the same percent while tuitions increased by about 30 percent until the 1760 s when real tuitions declined and returned to their initial level in the end of the period. In the case of the building trades and the leather products trades, again, the number of apprenticeships increased by 150-200 percent, tuitions responded moderately and real tuitions soon returned to their initial level. In all these cases there was a long-run increase in nominal tuitions.

These figures reflect very clearly the high level of flexibility of the supply in this market and its capacity of absorbing strong changes in demand for skill acquisition. In the next section, we provide more formal econometric evidence for this claim.

\section{INSTRUMENTAL VARIABLES (IV) REGRESSION ANALYSIS}

We now turn to the analysis of the elasticity of the tuition payments with respect to the number of apprenticeships:

$$
\left.\ln \left(\text { tuition }_{i, t}\right)=\alpha \ln \text { tuition }_{i, t-1}\right)+\beta_{1} \ln \left(\text { apprentices }_{i, t}\right)+X^{\prime} \delta+\gamma_{i}+\varepsilon_{i}
$$

where each observation represents an occupation $i$ (in London/Country) in year $t .^{32}$ Our dependent variable of interest is the logarithm of the tuition of occupation $\mathrm{i}$ in year $\mathrm{t}, \ln \left(\right.$ tuition $\left._{i, t}\right)$. The lagged value of this variable is included on the right-hand side to capture the persistence in

\footnotetext{
${ }^{32}$ The reason that we separate between observations from London and from the rest of the country is to account for London's special features being such a big center of apprenticeship. We do not use the county level because the number of observations in each group would be too small.
} 
tuitions. ${ }^{33}$ The $X$ matrix contains a set of covariates: CPI, the logarithm of unskilled wages (the wages of day laborers) and the logarithm of the number of war recruits, the percent of observations from London, and a linear time trend. ${ }^{34}$ All the covariates in $X$ vary only over time. ${ }^{35}$ The parameter $\gamma_{i}$ denotes a full set of London_occupational effects, which capture common shocks to tuitions of all occupations, and, $\varepsilon_{i}$ is an error term, capturing all other omitted factors. Our main variable of interest, $\ln \left(\right.$ apprentices $\left._{i, t}\right)$, is the number of new apprentices in occupation $\mathrm{i}$ in year $\mathrm{t}$. The parameter $\beta_{1}$ therefore, measures the elasticity of tuition with respect to the number of apprentices and the reciprocal of the standard elasticity of supply. However, $\beta_{1}$ cannot be consistently estimated using OLS since, as is typical when studying demand and supply, prices and quantities are mutually determined and observed in equilibrium. We therefore use an Instrumental Variable approach. ${ }^{36}$

In what follows, we propose death rates and the size of youth population (in logarithm) as instruments for the number of new apprentices. Apprentices were usually bound at the age of 14 and their number was affected by changes in the size of their cohort. One of the important factors that affected the size of cohorts in eighteenth century England was outbreaks of smallpox, which mostly affected children in the ages of $0-10$.

According to Romola Davenport, Leonard Schwarz, and Jeremy Boulton (2011) smallpox was the single most lethal cause of death in the eighteenth century, accounting for 6-10 percent of all burials. More importantly, although the knowledge of the geography of smallpox epidemics and mortality in eighteenth century England remains extremely fragmentary, smallpox was a childhood disease. For example, in London in 1752-1766 almost 80 percent of the deaths from smallpox were amongst children between the ages of 0 and 10 (about 70 percent amongst children between 0 and 4), and in 1775-1799, 94.2 percent (about 85 percent between 0 and 4). ${ }^{37}$ In Kilmarnock, Scotland, 94 percent

${ }^{33}$ The dynamic setting actually makes little difference. All the regression results remain similar when the lagged variable is omitted. Note that incorporating the lag of the dependent variable in the regression involves a loss of 894 observations due to the unbalanced nature of the panel.

${ }^{34}$ The percent of entries from London relative to Country is meant to capture possible effects of changes in the composition of entries that are not constant over time due to casual drops in the number of entries in one of the series.

${ }^{35}$ For sources and description of these variables see footnote 25 . We chose to specify the CPI as a right hand-side variable rather than a denominator of our dependent variable to allow for the possibility that its effect on tuition was not one. The main wars of this period were the Spanish Succession, the Austrian Succession, the Seven Years' War, and the French wars.

${ }^{36}$ Ryoo and Rosen (2004) for example use changes in R\&D expenditure in the United States as an instrument for changes in demand for engineering studies.

${ }^{37}$ Davenport, Schwarz, and Boulton (2011, Table 1, p. 1295). 


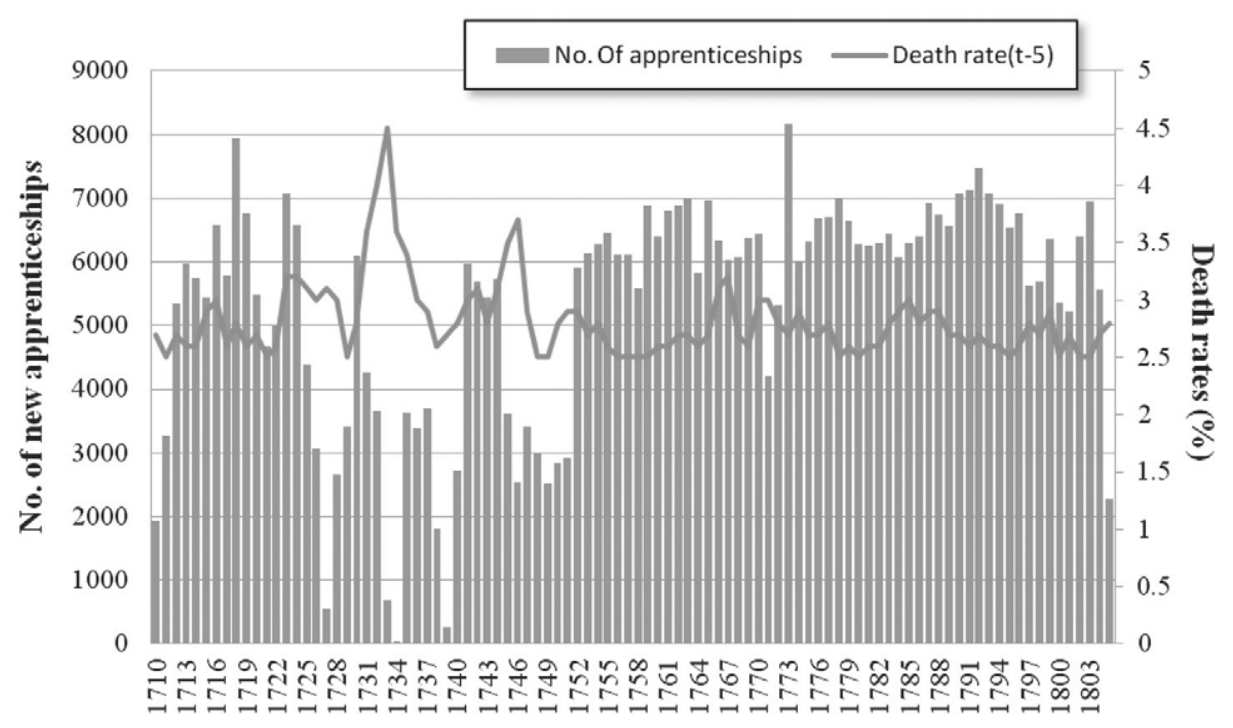

FIGURE 4

DEATH RATES AND THE NUMBER OF NEW APPRENTICESHIPS

Source: The number of apprentices is from the Stamp Tax Registers; for death rates see footnote 25.

of smallpox victims between 1728 and 1763 were aged under seven, and in Manchester only one adult (aged over 10) was recorded as dying, of 589 smallpox victims in the period $1769-1774 .{ }^{38}$ Changes in death rates can therefore be assumed to have had a stronger effect on the demand for apprenticeships (availability of children and willingness to send them to cities where smallpox hit harder) than on the supply of apprenticeships (supply of masters). Figure 4 illustrates the correlation between the number of apprentices and death rates, mainly when we look at the five year lag which was chosen to capture the high death rates from smallpox of children aged $0-10$, about five years before becoming apprentices. As the first stage Angrist-Pischke F statistics of weak identification in our regressions show, these IVs are strongly correlated with the number of new apprentices.

Note that since our instruments and all the covariates in $X$ vary only over time and not over occupation, we cannot add time fixed effects to regressions where these covariates are included. ${ }^{39}$ Nevertheless, as the results in columns (2) and (3) of Table 1a show, the covariates manage to capture most of the variation over time and are as good as using year fixed

\footnotetext{
${ }^{38}$ Ibid. p. 1298.

39 Although we cannot add year fixed effects our control variables account for most of the ongoing trends during this period. In addition, our results are maintained when a linear time trend is added to the regression, as reported in column (7) of Table 1.
} 
effects. As previously mentioned we control for changes in the composition of entries from "City" and "Country" registers in the analysis by adding the ratio of observations from "City" (Percent_London).

Column (1) in Table 1a presents the pooled OLS relationship between tuitions and the number of new apprentices. The elasticity of tuitions with respect to the number of new apprentices is statistically significant at the 1-percent level (all the standard errors are robust for arbitrary heteroscedasticity and clustering of the standard errors at the year and occupational level). The estimated elasticity increases when we add the London_occupation fixed effects. The estimate of $\beta_{1}$ in column (2) is 0.08 with a standard error of 0.008 . If causal, this estimate would imply that a percentage increase in the number of apprentices increased tuitions by 0.08 percentage points. Column (3) is identical to column (2) except for the year fixed effects which are replaced by the set of time varying covariates in $X$. The estimate of $\beta_{1}$ is very similar (0.088), suggesting that our covariates capture most of the annual common shocks to tuitions. The effects of the control variables on the tuitions are all as expected with an elasticity of 0.1 of tuitions with respect to prices. The coefficient estimate of the labor's nominal wages is not statistically significant due to the high degree of colinearity between wages and prices. It becomes significant at the 1-percent level once prices are dropped. The results remain practically unchanged when the lagged dependent variable is omitted as presented in column (4).

Since the number of apprentices is simultaneously determined and therefore endogenous, the estimates of $\beta_{1}$ in columns (1)-(4) are not consistent. Columns (5) and (6) present the two-stage least-squares estimate of $\beta_{1}$ which is now consistently estimated and is, as expected in cases of simultaneity, higher at the level of 0.2 in the dynamic setting in column (5) and 0.19 when we drop the lagged dependent variable in column (6). The results in column (7) are obtained after including all the years in the data without restricting for the annual number of entries and after dropping the variable Percent_London that we use to control for possible effects of the sharp declines in the number of entries in the data. The resulting estimate of $\beta_{1}$ in this case is much lower (0.047) and not significant. Panel B presents the first stage results for the regressions in columns (5)-(7). Our instrumental variables are shown to be highly correlated with the number of apprentices and, as the Angrist-Pischke F-statistic shows, the null hypothesis that the equation is weakly identified is rejected. ${ }^{40}$

\footnotetext{
${ }^{40} \mathrm{~A}$ problem that may arise in applying OLS to a dynamic model is a correlation of the lagged dependent variable in the right-hand side, $\ln \left(\right.$ tuition $\left._{i, t-1}\right)$, with the fixed effects in the error term. This problem however, diminishes here due to the long time dimension in our panel.
} 
TABLE 1A

OLS AND IV ESTIMATES OF THE ELASTICITY OF TUITIONS WITH RESPECT TO THE NUMBER OF APPRENTICES

\begin{tabular}{|c|c|c|c|c|c|c|c|}
\hline \multicolumn{8}{|c|}{ Panel A: Second Stage Regressions } \\
\hline & \multicolumn{7}{|c|}{ Dependent Variable: $\log$ (tuition) } \\
\hline & (1) & (2) & (3) & (4) & $(5)$ & (6) & (7) \\
\hline & $\begin{array}{l}\text { Pooled OLS } \\
\text { (with Year } \\
\text { Dummies) }\end{array}$ & $\begin{array}{l}\text { Fixed Effects } \\
\text { OLS (with } \\
\text { Year Dummies) }\end{array}$ & $\begin{array}{c}\text { Fixed Effects } \\
\text { OLS } \\
\text { (Dynamic) }\end{array}$ & $\begin{array}{l}\text { Fixed Effects } \\
\text { OLS } \\
\text { (Non-Dynamic) }\end{array}$ & $\begin{array}{c}\text { Fixed Effects } \\
\text { 2SLS } \\
\text { (Dynamic) }\end{array}$ & $\begin{array}{l}\text { Fixed Effects } \\
\text { 2SLS } \\
\text { (Non-Dynamic) }\end{array}$ & $\begin{array}{c}\text { Fixed Effects 2SLS } \\
\text { (No Control } \\
\text { for Data Gaps) }\end{array}$ \\
\hline \multirow[t]{2}{*}{ log (apprentices) $)_{\mathrm{t}}$} & $0.016^{* * *}$ & $0.081^{* * *}$ & $0.088^{* * *}$ & $0.103 * * *$ & $0.206 * * *$ & $0.189 * * *$ & 0.047 \\
\hline & $(0.005)$ & $(0.008)$ & $(0.008)$ & $(0.007)$ & $(0.065)$ & $(0.055)$ & $(0.033)$ \\
\hline \multirow[t]{2}{*}{$\log (\text { tuition })_{\mathrm{t}-1}$} & $0.754 * * *$ & $0.201 * * *$ & $0.203 * * *$ & & $0.184 * * *$ & & $0.201 * * *$ \\
\hline & $(0.009)$ & $(0.016)$ & $(0.016)$ & & $(0.019)$ & & $(0.016)$ \\
\hline \multirow[t]{2}{*}{$\mathrm{CPI}_{\mathrm{t}}$} & & & $0.099 * * *$ & $0.111^{* * *}$ & $0.122 * * *$ & $0.143 * * *$ & $0.084 * * *$ \\
\hline & & & $(0.024)$ & $(0.025)$ & $(0.027)$ & $(0.032)$ & $(0.026)$ \\
\hline \multirow[t]{2}{*}{$\log {\text { (laborers' wages) }{ }_{t}}$} & & & 0.037 & 0.105 & 0.051 & 0.048 & 0.045 \\
\hline & & & $(0.094)$ & $(0.097)$ & $(0.096)$ & $(0.104)$ & $(0.093)$ \\
\hline \multirow[t]{2}{*}{$\log (\text { war recruits })_{t}$} & & & $-0.015^{* *}$ & $-0.014 * *$ & $-0.012 *$ & -0.008 & $-0.015^{* *}$ \\
\hline & & & $(0.007)$ & $(0.007)$ & $(0.007)$ & $(0.008)$ & $(0.007)$ \\
\hline \multirow[t]{2}{*}{ Year (linear trend) } & & & $0.002 * * *$ & $0.002 * * *$ & $0.002 * * *$ & $0.002 * * *$ & $0.003 * * *$ \\
\hline & & & $(0.000)$ & $(0.000)$ & $(0.000)$ & $(0.000)$ & $(0.000)$ \\
\hline \multirow[t]{2}{*}{ Percent_London } & $0.003 * * *$ & $0.002 * * *$ & $0.001 * * *$ & $0.001 * * *$ & $0.001 * * *$ & $0.001 * * *$ & \\
\hline & $(0.000)$ & $(0.000)$ & $(0.000)$ & $(0.000)$ & $(0.000)$ & $(0.000)$ & \\
\hline FE (London_occupation) & No & Yes & Yes & Yes & Yes & Yes & Yes \\
\hline FE (year) & Yes & Yes & No & No & No & No & No \\
\hline No. of Observations & 11,559 & 11,559 & 11,559 & 12,429 & 11,559 & 12,429 & 11,971 \\
\hline R-Square & 0.615 & 0.738 & 0.733 & 0.700 & 0.721 & 0.693 & 0.724 \\
\hline No. of groups & & 146 & 146 & 146 & 146 & 146 & 148 \\
\hline
\end{tabular}


Panel B: First Stage Regressions

Dependent Variable: log (apprentices)

crude death rate $(\mathrm{t}-5)$

$-0.168 * *$

$-0.179 * * *$

$-0.435 * * *$

$(0.040)$

(0.041)

$(0.038)$

$\log ($ pop15)

$1.151 * * *$

$1.499 * * *$

$0.8244 * * *$

F-statistic for excluded instruments

$(0.219)$

$(0.224)$

$(0.223)$

* = Significant at 10 percent level.

$66.03 * * *$

$98.27 * * *$

$210.24 * * *$

** = Significant at 5 percent level.

$* * *=$ Significant at 1 percent level.

Notes: Dependent variable in second stage is the logarithm of tuitions. Columns (2)-(4) report the results of OLS regressions with fixed effects on the London-occupation level, with standard errors clustered at the year and occupation level. Columns (5)-(7) report IV regression results. The regression in column (7) does not control for the changes in the composition of the observation (the variable Percent_London) nor are the years with low numbers of observations dropped. F-statistic for excluded instruments gives the Angrist-

Pischke statistic. The null hypothesis is rejected at the 1 percent level in all cases. See Appendix Table 1 for variable definitions. Standard errors in parentheses.

Source: See text. 
Table $1 \mathrm{~b}$ presents our robustness checks to the two-stage least-squares estimates obtained in Table 1a. To test whether the results are mainly representative of apprenticeship in London, we run separate regressions for London and Country. The results in columns (1) and (2) show that tuitions in London responded more strongly to changes in the number of apprentices (a 0.39 estimated elasticity for London vs. 0.16 in the Country), yet, elasticities are still small and significantly lower than unity. This is an interesting result which may be interpreted as reflecting the stronger presence of guilds in London. Moreover, it may be reflecting London's concentration of apprenticeships to occupations with strong guilds (e.g., pewteres and goldsmiths) and with high entry costs (e.g., high setting up costs, prestiege), such as rich merchants and attorneys.

The regression in column (3) tests whether the estimates depend on the strong variation in the number of apprentices during the first half of the century, in which there are strong falls in the number of entries, by dropping the years 1710-1750 and shows this not to be the case. Columns (4)-(5) test for structural change examining whether the estimated elasticity changes throughout the period and present a moderate increase in the response of tuitions during the later part of the century, with an estimated elasticity of 0.16 between 1730 and 1770 and 0.24 between 1770 and 1805 . The results of an estimation excluding the years of the Napoleonic wars between France and Britain are presented in column (6) and column (7) presents the estimation excluding occupations related to machine making (the occupational group machines in Appendix Table 1). In both cases the estimated elasticity of tuitions with respect to the number of apprentices is low and significant ( 0.12 and 0.2 , respectively).

To test whether the estimated elasticities that we obtain vary across occupational groups we re-estimated our baseline regression from column (6) of Table 1a with the addition of an interaction term between the number of apprentices and a dummy variable representing the occupational category. The interaction of our two instruments with the same dummy variable was used to instrument for the additional endogenous variable. Table 2 presents the two-stage least-squares estimates for the elasticity of the tuition in the 13 occupational groups which include machinery, carpenters, building, shipbuilding, clothing, leather, wood, yarn, metal, victualing, services, trade, and other trades ${ }^{41}$ It is interesting to note that in almost all occupational categories we find no significance of the interaction term, implying that there is no significant difference in the elasticities between the different groups. The estimated elasticity

\footnotetext{
${ }^{41}$ For the occupations included in each occupational category see Appendix Table 1.
} 
TABLE 1B

THE ELASTICITY OF TUITIONS WITH RESPECT TO THE NUMBER OF APPRENTICES: ROBUSTNESS CHECKS

Panel A: Second Stage Regressions

$(1)$

Dependent Variable: $\log$ (tuition)

$(2)$

(3)

(4)

(5)

(6)

(7)

Period:

Only London Only Country Dropping Period with Omissions

Division to Sub-Period

No Napoleonic War Dropping Machines

$\log$ (apprentices) $1710-1805$ $1710-1805$ $1750-1805$ $1730-1770 \quad 1770-1805$ $1710-1793$ 1710-1805

Controls

$0.388 *$
$(0.231)$

$0.165 * *$

0.241 **

$0.164 * *$

$0.235 * * *$

$0.124 * *$

$0.204 * * *$

FE (occupation)

Yes

$(0.072)$

Yes

(0.081)

(0.081)

(0.054)

$(0.059)$

FE (year)

No. of Observations $\quad 5,763$

Yes

Yes

No

No

$5,763 \quad 4,771$

No

R-Square

0.651

4,771
0.796

7,793

Yes

Yes

No

No. of group

69

0.714

4,929

Yes

No

5,057

0.758

0.709

Yes
Yes

Yes

Panel B: First Stage Regressions

146

146

145

10,621

Yes

No

2,069

$60+146$

Dependent Variable: $\log$ (apprentices)

crude death rate ( $\mathrm{t}-5)$

0.041

$0.041--0.315^{* * *}$

$-0.381 * * *$

$(0.034) \quad(0.047) \quad(0.052)$

$\log ($ pop15)

$0.824 * * *$

$-0.181$

$-0.108^{*}$

$-0.68 * * *$

0.710

0.688

$\begin{array}{lll}(0.246) & (0.266) & (0.26)\end{array}$

F-statistic for excluded instruments

$11.36^{* * *}$

$74.71 * * *$

$60.96 * * *$

$\begin{array}{cc}(0.06) & (0.068) \\ 2.844 * * * & -0.618 *\end{array}$

$-0.256^{* * *}$

(0.042)

$(0.041)$

$*=$ Significant at 10 percent level.

** = Significant at 5 percent level.

$* * *=$ Significant at 1 percent level.

Notes: Dependent variable in the second stage is the logarithm of tuitions. All regressions are IV 2SLS regressions with fixed effects on the London-occupation level, with standard errors clustered at the year and occupation level. The specification of the regressions is the same as in coumn (6) of Table 1a but uses only observations from London (column (1)), only observations from the Country (column (2)), only observations from the years after 1750 (column (3)), columns (4)-(5) break the results of the two sub-periods: 1710-1770 (column (4)) and 1770-1805 (column (5)). In column (6), we omit the years of the Napoleonic wars (from 1792) and the column (7), we omit the occupational group machines. F-statistic for excluded instruments gives the Angrist-Pischke statistic. The null hypothesis is rejected at the 1 percent level in all cases. See Appendix Table 1 for variable definitions. Standard errors in parentheses.

Source: See text. 
TABLE 2

THE ELASTICITY OF TUITIONS WITH RESPECT TO THE NUMBER OF APPRENTICES: VARIOUS OCCUPATIONAL GROUPS

Panel A: Second Stage Regressions

\begin{tabular}{|c|c|c|c|c|c|c|c|c|c|c|c|c|c|}
\hline & \multicolumn{13}{|c|}{ Dependent Variable: $\log$ (tuition) } \\
\hline & (1) & (2) & (3) & (4) & (5) & (6) & (7) & (8) & (9) & (10) & (11) & (12) & (13) \\
\hline & Machinery & Carpenters & Building & Ship Building & Clothing & Leather & Wood & Yarn & Metal & Victualling & Other & Services & Trade \\
\hline \multirow[t]{2}{*}{$\log$ (apprentices) } & $0.200^{* * *}$ & $0.195 * * *$ & $0.194 * * *$ & $0.191^{* * *}$ & $0.203 * * *$ & $0.135 * *$ & $0.176^{* * *}$ & $0.220^{* * *}$ & 0.139 ** & $0.154 * * *$ & $0.193 * * *$ & $0.190 * * *$ & $0.217 * * *$ \\
\hline & $(0.059)$ & $(0.059)$ & $(0.057)$ & $(0.055)$ & $(0.063)$ & $(0.059)$ & $(0.056)$ & $(0.058)$ & $(0.057)$ & $(0.056)$ & $(0.056)$ & $(0.059)$ & $(0.057)$ \\
\hline \multirow{3}{*}{$\begin{array}{l}\log \text { (apprentices)* } \\
\text { occ_group }\end{array}$} & & & & & & & & & & & & & \\
\hline & -0.072 & -0.056 & -0.076 & -0.049 & -0.077 & $0.276^{* *}$ & $-0.764^{* *}$ & -0.021 & 0.462 & 0.443 & 0.007 & 0.238 & -0.182 \\
\hline & $(0.061)$ & $(0.056)$ & $(0.093)$ & $(0.251)$ & $(0.076)$ & $(0.125)$ & $(0.315)$ & $(0.128)$ & $(0.350)$ & $(0.408)$ & $(0.261)$ & $(0.308)$ & $(0.124)$ \\
\hline Controls & Yes & Yes & Yes & Yes & Yes & Yes & Yes & Yes & Yes & Yes & Yes & Yes & Yes \\
\hline FE (occupation) & Yes & Yes & Yes & Yes & Yes & Yes & Yes & Yes & Yes & Yes & Yes & Yes & Yes \\
\hline FE (year) & No & No & No & No & No & No & No & No & No & No & No & No & No \\
\hline No. of Observations & 12,429 & 12,429 & 12,429 & 12,429 & 12,429 & 12,429 & 12,429 & 12,429 & 12,429 & 12,429 & 12,429 & 12,429 & 12,429 \\
\hline R-Square & 0.691 & 0.693 & 0.693 & 0.693 & 0.692 & 0.690 & 0.674 & 0.687 & 0.669 & 0.687 & 0.692 & 0.687 & 0.693 \\
\hline No. of groups & 146 & 146 & 146 & 146 & 146 & 146 & 146 & 146 & 146 & 146 & 146 & 146 & 146 \\
\hline
\end{tabular}

Panel B: First Stage Regressions

Dependent Variable: $\log$ (apprentices)

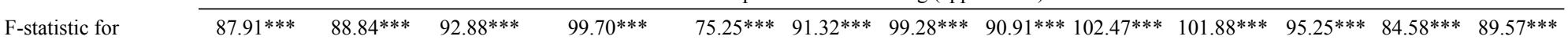

excluded instruments

Dependent Variable: $\log$ (apprentices)*occ_group

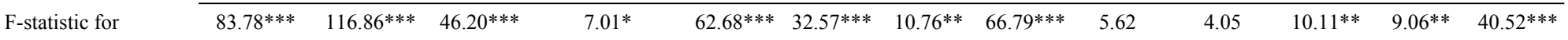
excluded instruments

* = Significant at 10 percent level.

** = Significant at 5 percent level.

$* * *=$ Significant at 1 percent level.

Notes: Dependent variable in the second stage is the logarithm of tuitions. All regressions are IV 2SLS regressions with fixed-effects on the London-occupation level, with standard errors clustered at the year and occupation level. The specification of the regressions is the same as in column (6) of Table 1a with the addition of an interaction of our variable of interest, log(apprentices) with an occupational group (containing a number of occupations specified in Appendix Table 1). F-statistic for excluded instruments gives the Angrist-Pischke statistic. The null hypothesis is rejected at the 1 percent level in all cases. See Appendix Table 1 for variable definitions. Standard errors in parentheses.

Source: See text. 
in the leather and wood categories came out significantly different than the average, however this should be interpreted with caution as the probability of obtaining sigificant results for 2 out of 13 by chance is high and there is no apriori reason to expect different results in these two groups. ${ }^{42}$ This does not mean however that there were no differences in elasticities within groups, between the occupations composing them.

The regression analysis presented in this section leads us to two important conclusions. The first is that the supply of apprenticeships in eighteenth century England was highly elastic. The system of apprenticeship could absorb important changes in the demand, as was the case with machinery workers and carpenters, without a strong response of the tuition. Our second conclusion is that this capacity was representative of the system as a whole and did not vary significantly between trades, while demand for apprenticeship did vary with the nature of final demand and the shocks to technology.

\section{IDENTIFYING DEMAND SHOCKS USING A VAR}

We now employ a VAR to test the short-run and long-run response of both the number of apprentices and the tuition to technological changes, for which we use the innovation in the textile technology series. ${ }^{43} \mathrm{We}$ perform the analysis in the aggregate level, as well as in specific occupational groups. The results are summarized in Table 3. The table shows the sectoral responses of the quantities and prices of apprenticeships to a one unit increase in textile technological innovations (that is, one more significant invention in the textile industry) from VARs that examine the impact of these innovations on sectoral apprenticeship quantity and tuition series. ${ }^{44}$

The response horizon reported in column 1 of the table is the number of years following the shock at which each peak quantity response is obtained; this is the horizon which corresponds to the reported quantity and tuition responses (columns 2 and 3, respectively). The table shows that the number of apprenticeships responded significantly to inventions in most occupational sectors, mainly in the sectors relevant to the inventions in this period, including, metalwork and leather that were directly required for machine construction, in yarn and clothing, in which production increased and in building (including carpenters), due to increase in

\footnotetext{
42 These results are not significant according to the Bonferroni test (a method used to correct any set of p-values for multiple comparisons).

${ }^{43}$ See section "The Dataset."

${ }^{44}$ The details of the analysis are available from the authors upon request.
} 
TABLE 3

SECTORAL RESPONSES AND IMPLIED SUPPLY ELASTICITIES INDUCED BY A ONE UNIT INCREASE IN TEXTILE TECHNOLOGICAL INNOVATIONS

\begin{tabular}{lcccc}
\hline \hline & $\begin{array}{c}\text { Peak Quantity } \\
\text { Response } \\
\text { Horizon } \\
(1)\end{array}$ & $\begin{array}{c}\text { Quantity } \\
\text { Response } \\
\text { (in Percent) }\end{array}$ & $\begin{array}{c}\text { Tuition } \\
\text { Response } \\
\text { (in Percent) }\end{array}$ & $\begin{array}{c}\text { Implied } \\
\text { Price }\end{array}$ \\
\cline { 3 - 5 } Building trades & 6 & $45.2^{* * *}$ & $7.2^{* *}$ & $\begin{array}{c}\text { Elasticity } \\
(4)\end{array}$ \\
Carpenters and joiners & 5 & $58.4^{* * *}$ & $10.9^{* * *}$ & 0.2 \\
Clothing and upholstery & 4 & $46.6^{* *}$ & $16.2^{* * *}$ & 0.2 \\
Instrument and machines & 5 & $65.0^{* * *}$ & $5.1^{* *}$ & 0.3 \\
Leather and leather goods & 5 & $44.0^{* * *}$ & $10.6^{* * *}$ & 0.1 \\
Metalwork & 5 & $42.0^{* * *}$ & $15.6^{* * *}$ & 0.2 \\
Ship builders & 2 & 27.3 & -2.9 & 0.4 \\
Smiths and founders & 3 & $32.7^{*}$ & -3.7 & -0.1 \\
Victualling trades & 4 & $21.3^{*}$ & 3.8 & -0.1 \\
Wood workers, carvers, and turners & 3 & 20.2 & -0.7 & 0.2 \\
Yarn and cloth & 4 & 21.9 & $17.2^{* * *}$ & 0.0 \\
\hline
\end{tabular}

$*$ = Significant at 10 percent level.

** = Significant at 5 percent level.

$* * *=$ Significant at 1 percent level.

Notes: The table shows the sectoral responses of the quantities and prices of apprenticeships to a one unit increase in textile technological innovations from VARs that include the textile technological innovations series along with sectoral apprenticeship quantity and tuition series. The response horizon reported in the first column is the number of years following the shock at which each peak quantity response is obtained; this is the horizon which corresponds to the reported quantity and tuition responses (columns 2 and 3 , respectively). The fourth column reports the implied price elasticities, computed as the ratio of the tuition response to the quantity response.

Statistical significance results are based on Hall (1992) confidence bands generated from a residual based bootstrap procedure repeated 2,000 times.

Source: See text.

construction. It can be seen that machinery demonstrated the largest quantity responses (65 percent). This is not surprising as this sector includes occupations that are highly skilled and directly relevant to the machinery production and maintenance and are therefore expected to be in demand when technological change take place. ${ }^{45}$

Moreover, the evidence for the sectors for which there are statistically significant responses is consistent with our interpretation of the technology shocks as demand shocks: tuition levels rise considerably following all shocks, indicating that there is a strong shift in demand for apprenticeships that pushes prices up along with quantities. For example, tuitions in the metalwork, building trades, and clothing and upholstery rise by $15.6,7.2$, and 16.2 percent, respectively.

The fourth column of the table reports the implied price elasticities, computed as the ratio of the tuition response to the quantity response. By

\footnotetext{
${ }^{45}$ Statistical significance results are based on Hall (1992) confidence bands generated from a residual based bootstrap procedure repeated 2,000 times.
} 
and large, we can see that the elasticity of prices was sufficiently low so as to allow for quantities to rise considerable following the technology shock. These results are broadly consistent with those presented in Table 1a and it is encouraging that despite the very different methodologies employed the order of magnitude of the estimated (inverse) supply elasticity of 0.2 reported in column 5 of Table $1 \mathrm{a}$, is quite similar to the sectoral elasticities obtained by the VAR analysis and reported in column 4 of Table 3. Note that the elasticities computed in column 4 of Table 3 are not the same parameter as those estimated in Table 1a; the latter are the marginal elasticities, whereas the former can be viewed as the accumulated elasticities over a particular number of years. Notwithstanding this difference, it is encouraging that these two types of estimated elasticities are broadly similar. Both point to a highly elastic supply curve of skills, and thus indicate a high degree of adaptability of the economy to technological shocks.

We now examine the dynamics of tuition and apprenticeship quantities following the technology shocks. Towards this end, we also present the estimated impulse responses for the aggregate apprenticeship quantity and tuition series (Figure 5) as well as for the instrument and machines sector and the carpenters and joiners sector (Figures 6 and 7). We focus on these two sectors for conciseness reasons but also because these two sectors seem to be most sensitive to technology shocks exhibiting the largest quantity responses.

Note that the aggregate VAR is different from the sectoral VARs only in that aggregate quantity and price series are used instead of sectoral ones. Figure 5 depicts the estimated impulse responses of the textile technological innovations series and the aggregate apprenticeship quantity and tuition series to a positive one standard deviation unanticipated technology shock, along with the 5th and 95th percentile confidence bands. Turning first to the aggregate apprenticeship quantity series, it is evident that the impact response is overall statistically insignificant, after which the quantity rises in a hump-shaped manner peaking at 8.2 percent after four years. Following the technology shock, the number of inventions rises significantly on impact by 0.26 inventions, after which it exhibits a hump-shaped response that peaks after one year at 0.55 inventions. Moreover, the impact response of the aggregate tuition series is at first insignificant, but becomes significant after three years and peaks after 6 years reaching 2.7 percent.

Figure 6 depicts the estimated impulse responses of the textile technological innovations series and the instrument and machinery apprenticeship quantity and tuition series to a positive one standard deviation unanticipated technology shock, along with the 5th and 95th percentile 

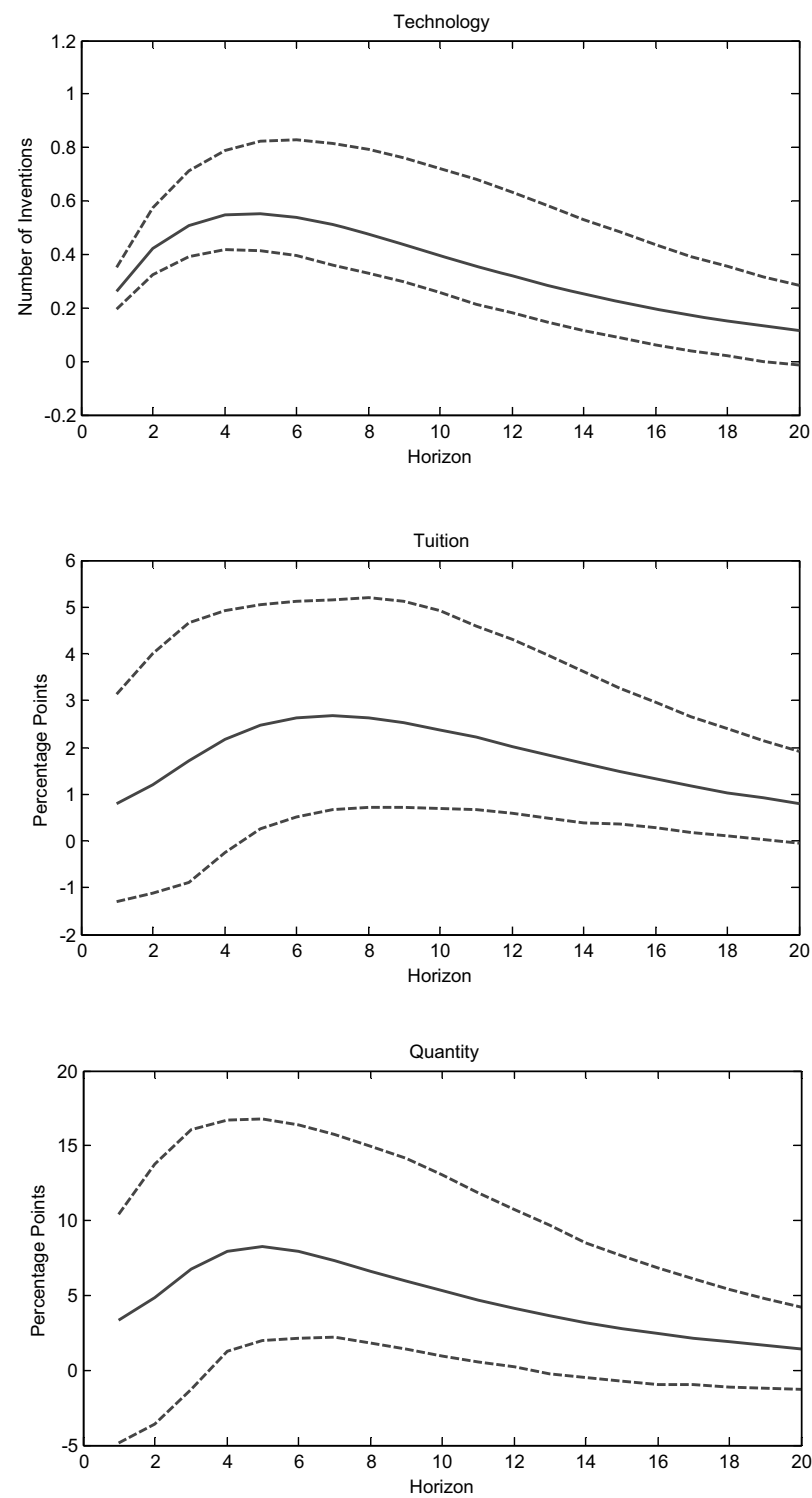

FIGURE 5

IMPULSE RESPONSES TO A ONE STANDARD DEVIATION TECHNOLOGY SHOCK (SOLID LINES): OVERALL AGGREGATE ECONOMY

Source: See text.

confidence bands. The number of inventions significantly rises in a humpshaped manner peaking after four years at 0.55 inventions. The responses of the quantity and tuition series, however, are considerably stronger than those of the aggregate series. In particular, the quantity of apprenticeships rises by 10.6 percent on impact, after which it continues to increase peaking at 16.9 percent four years following the shock. The response is 

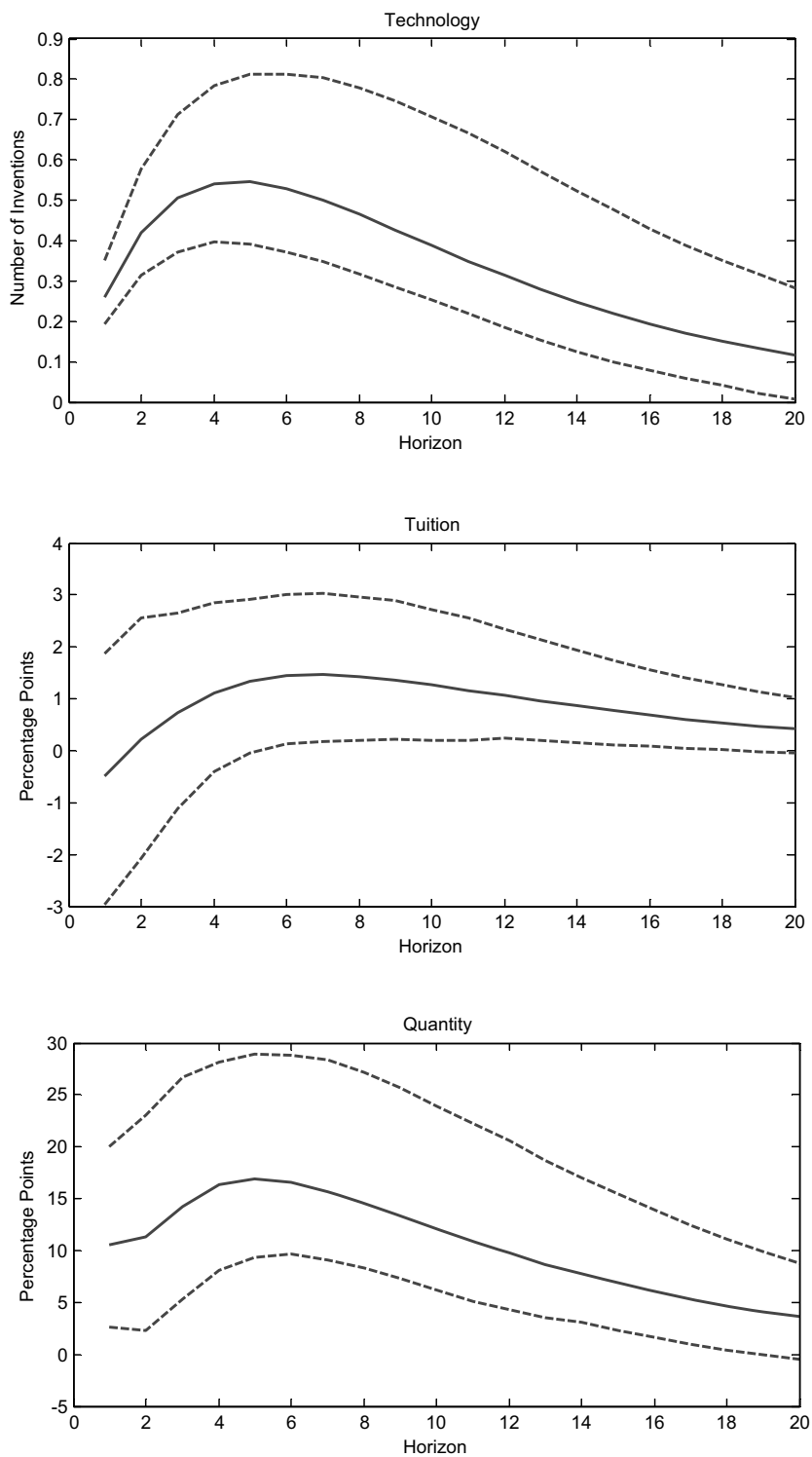

FIGURE 6

IMPULSE RESPONSES TO A ONE STANDARD DEVIATION TECHNOLOGY SHOCK (SOLID LINES): INSTRUMENTS AND MACHINERY SECTOR

Source: See text.

both and statistically and economically significant. The tuition series also exhibits a similar hump-shaped response, although it is smaller relative to the quantity series and only becomes significant after four years. The tuition peak response takes place after six years reaching 1.5 percent. Overall, it is apparent that the instruments and machinery apprenticeship market reacts in a significant manner to the technology shock. 

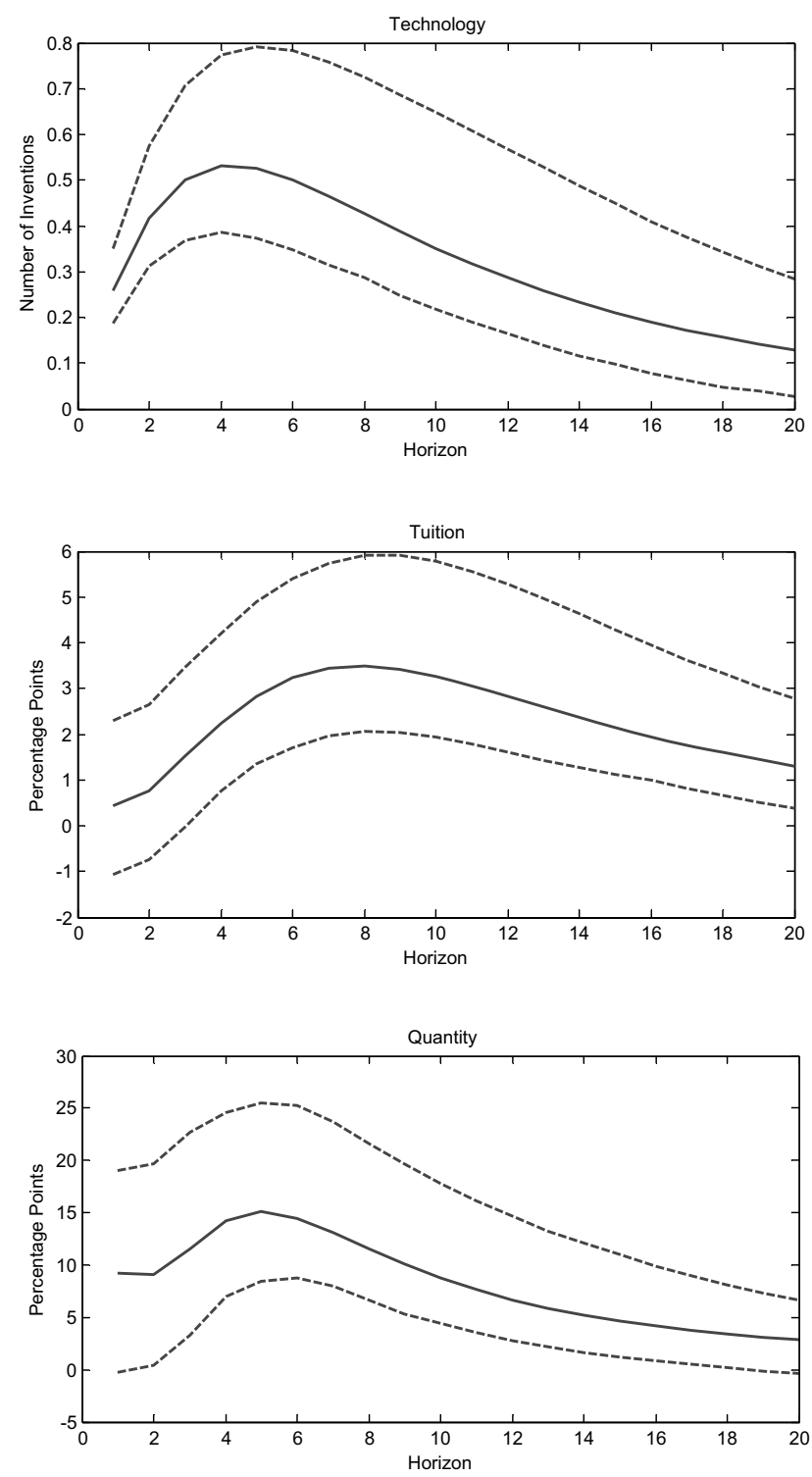

FIGURE 7

IMPULSE RESPONSES TO A ONE STANDARD DEVIATION TECHNOLOGY SHOCK (SOLID LINES): CARPENTERS AND JOINERS

Source: See text.

Figure 7 depicts the estimated impulse responses of the textile technological innovations series and the carpenters apprenticeship quantity and tuition series to a positive one standard deviation unanticipated technology shock, along with the 5th and 95th percentile confidence bands. The responses of all variables are generally similar to those in Figure 6, although the tuition response is much stronger than the tuition response 
TABLE 4

SECTORAL RESPONSES AND IMPLIED SUPPLY ELASTICITIES INDUCED BY A ONE UNIT INCREASE IN PATENTS

\begin{tabular}{|c|c|c|c|c|}
\hline & $\begin{array}{c}\text { Peak Quantity } \\
\text { Response } \\
\text { Horizon } \\
\text { (1) }\end{array}$ & $\begin{array}{c}\text { Quantity } \\
\text { Response } \\
\text { (in Percent) } \\
\text { (2) }\end{array}$ & $\begin{array}{c}\text { Tuition } \\
\text { Response } \\
\text { (in Percent) } \\
\text { (3) }\end{array}$ & $\begin{array}{c}\text { Implied } \\
\text { Price } \\
\text { Elasticity } \\
\text { (4) }\end{array}$ \\
\hline Building trades & 2 & $0.8 *$ & 0.1 & 0.1 \\
\hline Carpenters and joiners & 2 & $1.0 *$ & $0.2 * *$ & 0.2 \\
\hline Clothing and upholstery & 2 & $0.9 * *$ & $0.3 *$ & 0.3 \\
\hline Instrument and machines & 2 & $1.1 * *$ & $0.2^{*}$ & 0.2 \\
\hline Leather and leather goods & 2 & $1.2 * *$ & $0.4^{*}$ & 0.3 \\
\hline Metalwork & 3 & $0.7 * *$ & $0.5^{*}$ & 0.6 \\
\hline Ship builders & 2 & 0.0 & 0.2 & 6.9 \\
\hline Smiths and founders & 2 & 0.4 & 0.1 & 0.3 \\
\hline Victualling trades & 2 & $0.9 *$ & 0.3 & 0.4 \\
\hline Wood workers, carvers, and turners & 2 & 0.5 & 0.0 & 0.1 \\
\hline Yarn and cloth & 4 & $0.6^{*}$ & $0.4^{*}$ & 0.6 \\
\hline
\end{tabular}

* = Significant at 10 percent level.

** = Significant at 5 percent level.

*** = Significant at 1 percent level.

Notes: The table shows the sectoral responses of the quantities and prices of apprenticeships to a one unit increase in the patent series from VARs that include the textile technological innovations series along with sectoral apprenticeship quantity and tuition series. The response horizon reported in the first column is the number of years following the shock at which each peak quantity and tuition responses (columns 2 and 3 , respectively). The fourth column reports the implied price elasticities, computed as the ratio of the tuition response to the quantity response.

Statistical significance results are based on Hall (1992) confidence bands generated from a residual based bootstrap procedure repeated 2000 times.

Source: See text.

in the instruments and machinery sector, indicating a higher sensitivity of the level of tuition in the carpenters apprenticeship market relative to the instruments and machinery apprenticeship market. Moreover, the quantity response is both statistically significant as well as economically significant (the peak response of carpenters' apprenticeships is 15.1 percent and takes place after one year).

\section{Results from Using Patent Data}

As a robustness check, we have also conducted the analysis described in the previous section for the case in which technology is measured by the annual number of patents weighted by the Woodcroft's Reference Index that aims at capturing the significance of a patent by the number of citations it has in the contemporary technical literature. The results are summarized in Table 4. The table shows the sectoral responses of the quantities and prices of apprenticeships to a one unit increase in the 
patent serie from VARs that examine the impact of these patents on sectoral apprenticeship quantity and tuition series.

Overall, it is clear that the main conclusions from the previous sections are confirmed also when we consider the alternative patent series. Price elasticities continue to be low and generally quite similar in quantitative terms to those from Table 3 . The sectors for which sigificant response are obtained are nearly identical to those from the baseline case, with the exception that now the yarn and cloth sector also exhibits siginificant responses. In sum, these results confirm that our baseline conclusions are not driven by the choice of the technology series measure.

\section{CONCLUSION}

As many scholars have recently recognized, the skills and highquality craftsmanship that the British apprenticeship system provided the country with one of the main advantages that explain the early onset of the Industrial Revolution in Britain (Humphries 2003; Kelly, Mokyr, and Ó Gráda 2014). It has been widely recognized that this was made possible by a relatively free and flexible market for skills, in which young lads were matched to masters (Leunig, Minns, and Wallis 2011). But not all markets are created the same. The characteristics of the British economy that were responsible for the allocation of resources toward the production of this human capital have been widely regarded as consisting of three elements. One was the weakness of the guilds in Britain, which made for flexible and adaptable markets for human capital. Our findings are consistent with the hypothesis that Britain's training system was far more effective and flexible than any other European economy, although an exact comparison is not possible in the absence of comparable datasets for other economies. A second was the reliance of self-enforcing, privateorder institutions that made sure that the contract between master and apprentice was enforced (Mokyr 2008). A third was that this market was cleared by a set of prices, namely the premiums paid by the apprentices or their parents.

Yet none of these would have mattered much had it not been that the supply of human capital was reasonably elastic in the medium and long run, with adjustment happening both at the intensive and extensive margins. In this article, we use data on both the number of apprentices and the premiums paid by their parents or guardians to estimate the dynamic supply-responsiveness in this market in the presence of the increasingly powerful technology shocks administered to it as the Industrial Revolution proceeded apace. Using both an instrumental variables methods to estimate the market for apprenticeship and a dynamic VAR 
system to identify the long-run reponse functions, we find evidence of an elastic supply response to shocks, which suggests that these responses were indeed regulated by market prices, lending support to the marketbased view of this institution.

The finding has significant implications for our understanding of the British Industrial Revolution. While many of the inventions took place in Britain, the technological advances were European, with a large number of significant inventions made by non-British inventors. Why, then, was Britain first? One of the areas where Britain's advantage seems most pronounced is in its ability to "scale-up" from models and blueprints into actual production, to install, operate, and maintain complicated mechanical devices, and to introduce continuous adaptations and minor improvements that were critical to their economic success. These characteristics did not require much science or even originality, but they needed people who were good with their hands and had been taught how to use them. It is that resource that the apprenticeship institution in Britain supplied better than anywhere else.

\section{Appendix 1: Summary Statistics}

APPENDIX TABLE 1

SUMMARY STATISTICS BY OCCUPATIONS

\begin{tabular}{|c|c|c|c|c|c|c|}
\hline \# & $\begin{array}{l}\text { Occupational } \\
\text { Group }\end{array}$ & Occupation & $\begin{array}{c}\text { Average No. } \\
\text { of New } \\
\text { Apprentices }\end{array}$ & Std & $\begin{array}{l}\text { Average } \\
\text { Tuition } \\
\text { (£.) }\end{array}$ & Std \\
\hline 1 & Building & Brick layer & 16.63 & 8.40 & 7.38 & 2.86 \\
\hline 2 & & Glazier & 14.75 & 6.87 & 12.94 & 6.96 \\
\hline 3 & & Other building trades & 14.11 & 8.45 & 15.05 & 11.17 \\
\hline 4 & & Plumber & 23.53 & 16.05 & 14.35 & 3.06 \\
\hline 5 & & Stone mason & 17.57 & 15.54 & 11.23 & 11.52 \\
\hline 6 & Carpenters & Cabinet maker & 34.88 & 27.85 & 18.26 & 5.92 \\
\hline 7 & & Coach maker & 14.18 & 11.69 & 29.63 & 9.12 \\
\hline 8 & & House carpenter & 174.23 & 88.76 & 10.59 & 3.05 \\
\hline 9 & & Joiner & 73.14 & 37.98 & 13.65 & 3.94 \\
\hline 10 & Clothing & Coat and mantua maker & 53.72 & 25.42 & 15.08 & 4.82 \\
\hline 11 & & Milliner & 33.93 & 22.52 & 26.55 & 5.68 \\
\hline 12 & & Other textile trades & 31.07 & 37.71 & 11.56 & 14.28 \\
\hline 13 & & Sail maker & 7.67 & 5.61 & 19.76 & 9.50 \\
\hline 14 & & Stay maker & 10.98 & 7.54 & 10.56 & 4.07 \\
\hline 15 & & Tailor & 173.44 & 82.66 & 11.26 & 4.59 \\
\hline 16 & & Upholder & 12.31 & 6.95 & 38.58 & 11.21 \\
\hline 17 & Leather & Coach leather currier & 22.07 & 11.20 & 20.20 & 8.02 \\
\hline 18 & & Collar maker & 13.18 & 6.94 & 11.20 & 3.60 \\
\hline 19 & & Furrier and skinner & 6.64 & 4.67 & 33.91 & 40.14 \\
\hline 20 & & Glover & 32.69 & 19.71 & 16.62 & 10.23 \\
\hline
\end{tabular}


APPENDIX TABLE 1 (CONTINUED) SUMMARY STATISTICS BY OCCUPATIONS

\begin{tabular}{|c|c|c|c|c|c|c|}
\hline \# & $\begin{array}{l}\text { Occupational } \\
\text { Group }\end{array}$ & Occupation & $\begin{array}{c}\text { Average No. } \\
\text { of New } \\
\text { Apprentices }\end{array}$ & Std & $\begin{array}{l}\text { Average } \\
\text { Tuition } \\
(£ .)\end{array}$ & Std \\
\hline 21 & & Hatter and felt maker & 12.30 & 6.61 & 15.31 & 9.43 \\
\hline 22 & & Other leather trades & 8.56 & 5.08 & 20.35 & 14.67 \\
\hline 23 & & Saddler & 34.90 & 17.84 & 19.10 & 5.35 \\
\hline 24 & & Shoe maker & 284.00 & 159.74 & 7.28 & 1.80 \\
\hline 25 & & Tanner & 15.92 & 9.30 & 33.41 & 28.90 \\
\hline 26 & Machines & Engineers and wrights & 78.33 & 51.24 & 10.96 & 5.27 \\
\hline 27 & & Machine and instrument makers & 42.54 & 22.26 & 17.22 & 5.27 \\
\hline$\overline{28}$ & Other & Artists and luxury product makers & 19.73 & 11.09 & 26.93 & 15.04 \\
\hline 29 & & Other trades & 31.74 & 14.26 & 25.61 & 10.71 \\
\hline 30 & Services & Apothecary & 33.89 & 20.95 & 64.04 & 24.14 \\
\hline 31 & & Barber and periwig maker & 72.16 & 53.40 & 12.26 & 7.00 \\
\hline 32 & & Education & 4.39 & 4.31 & 21.70 & 12.58 \\
\hline 33 & & Juridical services & 87.62 & 72.96 & 108.48 & 34.11 \\
\hline 34 & & Mariner & 10.47 & 11.11 & 16.99 & 11.50 \\
\hline 35 & & Medical trades & 53.55 & 30.57 & 70.72 & 20.57 \\
\hline 36 & & Other administrative & 8.50 & 7.80 & 74.79 & 77.10 \\
\hline 37 & & Other services & 9.75 & 5.92 & 29.36 & 23.88 \\
\hline 38 & Shipbuilding & Ship builder & 46.64 & 34.43 & 18.08 & 5.79 \\
\hline 39 & Smiths_metal & Brazier & 12.43 & 7.32 & 14.19 & 5.19 \\
\hline 40 & & Cutler & 9.43 & 6.60 & 19.71 & 12.72 \\
\hline 41 & & Goldsmith/silversmith & 17.78 & 16.68 & 31.87 & 13.69 \\
\hline 42 & & Gun and lock smiths & 5.02 & 2.61 & 12.72 & 5.99 \\
\hline 43 & & Jeweller & 7.28 & 6.65 & 25.95 & 15.35 \\
\hline 44 & & Other metal trades & 25.10 & 11.67 & 18.67 & 10.45 \\
\hline 45 & & Other smiths and founders & 8.59 & 6.14 & 17.82 & 13.52 \\
\hline 46 & & Pewterer & 5.92 & 5.47 & 22.67 & 15.86 \\
\hline 47 & & Printing and engraving & 13.68 & 12.70 & 22.04 & 9.35 \\
\hline 48 & & Smith & 78.18 & 38.99 & 7.47 & 3.18 \\
\hline 49 & Trade & Clothier & 10.43 & 7.39 & 56.76 & 47.84 \\
\hline 50 & & Felt monger & 6.25 & 4.16 & 14.91 & 14.48 \\
\hline 51 & & Fish monger & 8.49 & 5.96 & 62.42 & 58.53 \\
\hline 52 & & Grocer's shop & 64.33 & 34.59 & 42.30 & 16.18 \\
\hline 53 & & Haberdasher & 16.86 & 16.38 & 48.09 & 20.87 \\
\hline 54 & & Ironmonger & 14.47 & 6.73 & 55.95 & 24.30 \\
\hline 55 & & Linen draper & 14.73 & 11.60 & 66.12 & 26.47 \\
\hline 56 & & Mercer & 25.12 & 22.19 & 55.96 & 22.55 \\
\hline 57 & & Other merchants & 70.90 & 37.45 & 75.38 & 31.53 \\
\hline 58 & & Stationer & 15.86 & 13.53 & 39.49 & 25.79 \\
\hline 59 & & Vintner & 13.16 & 18.22 & 34.46 & 29.29 \\
\hline 60 & & Woolen draper & 21.37 & 11.47 & 59.00 & 20.73 \\
\hline 61 & Victualling & Baker & 82.59 & 39.46 & 11.08 & 2.32 \\
\hline 62 & & Brewing and distilling & 7.28 & 7.75 & 77.02 & 84.68 \\
\hline 63 & & Butcher & 95.47 & 42.33 & 10.76 & 3.48 \\
\hline 64 & & Miller & 13.27 & 11.20 & 14.72 & 10.38 \\
\hline 65 & & Other victualling trades & 12.45 & 5.87 & 15.70 & 13.52 \\
\hline
\end{tabular}




\begin{tabular}{|c|c|c|c|c|c|c|}
\hline & & $\begin{array}{r}\text { APPENDIX TABLE } \\
\text { SUMMARY STATISTIC }\end{array}$ & $\begin{array}{l}\text { CONTINUED) } \\
\text { Y OCCUPA }\end{array}$ & & & \\
\hline \# & $\begin{array}{l}\text { Occupational } \\
\text { Group }\end{array}$ & Occupation & $\begin{array}{l}\text { Average No. } \\
\text { of New } \\
\text { Apprentices }\end{array}$ & Std & $\begin{array}{l}\text { Average } \\
\text { Tuition } \\
(£ .)\end{array}$ & Std \\
\hline 66 & Wood & Carver & 6.99 & 6.01 & 18.98 & 8.61 \\
\hline 67 & & Cooper & 67.95 & 29.89 & 14.67 & 4.89 \\
\hline 68 & & Other wood trades & 21.46 & 14.47 & 13.20 & 5.53 \\
\hline 69 & & Turner in wood & 16.31 & 7.72 & 12.33 & 5.89 \\
\hline 70 & Yarn_cloth & Dyer & 7.12 & 5.05 & 18.88 & 13.08 \\
\hline 71 & & Other yarn and cloth preparation & 21.91 & 10.61 & 24.11 & 19.21 \\
\hline 72 & & Weaver & 99.47 & 68.26 & 15.26 & 10.42 \\
\hline 73 & & Wool comber & 14.29 & 13.06 & 10.23 & 6.07 \\
\hline & Total & & 36.70 & 57.15 & 27.11 & 29.66 \\
\hline
\end{tabular}

\section{REFERENCES}

Allen, Robert C. "The Great Divergence in European Prices and Wages from the Middle Ages to the First World War.” Explorations in Economic History 38, no. 4 (2001): 411-47.

. "The Industrial Revolution in Miniature: The Spinning Jenny in Britain, France, and India." Journal of Economic History 69, no. 4 (2009): 901-27.

Becker, Sascha, Erik Hornung, and Ludger Woessmann. "Education and Catch-up in the Industrial Revolution." AEJ: Macroeconomics 3, no. 3 (2011): 92-126.

Berlin, Michael. "Guilds in Decline? London Livery Companies and the Rise of a Liberal Economy, 1600-1800.” In Guilds, Innovation and the European Economy, 1400-1800, edited by S. R. Epstein and Maarten Prak, 316-41. Cambridge: Cambridge University Press, 2008.

Board of Stamps: Apprenticeship Books, Series IR 1; The National Archives of the UK (TNA), Kew, Surrey, England.

Campbell, Robert. The London Tradesman. London, U.K.: T. Gardner, 1747. Reissued in facsimile form by Kessinger Publishing, Breiningsville, PA, 2010.

Clark, Gregory. "The Condition of the Working-Class in England, 1209-2004." Journal of Political Economy 113, no. 6 (2005): 1307-40.

- A Farewell to Alms: A Brief Economic History of the World. Princeton, NJ: Princeton University Press, 2007.

Clark, Peter. British Clubs and Societies, 1580-1800: The Origins of an Associational World. Oxford: Clarendon Press, 2000.

Crowston, Clare. "From School to Workshop: Pre-training and Apprenticeship in Old Regime France." In Learning on the Shop Floor: Historical Perspectives on Apprenticeship, edited by Bert De Munck, Steven L. Kaplan, and Hugo Soly, 46-62. New York: Berghahn Books, 2007.

Darnton, Robert. The Great Cat Massacre and Other Episodes in French Cultural History. New York: Basic Books, 1984.

Davenport, Romola, Leonard Schwarz, and Jeremy Boulton. "The Decline of Adult Smallpox in Eighteenth Century London.” Economic History Review 64, no. 4 (2011): 1289-314. 
Davids, Karel. “Apprenticeship and Guild Control in the Netherlands, c. 1450-1800.” In Learning on the Shop Floor: Historical Perspectives on Apprenticeship, edited by Bert De Munck, Steven L. Kaplan, and Hugo Soly, 65-84. New York: Berghahn Books, 2007.

De Munck, Bert. "Corpses, Live Models, and Nature: Assessing Skills and Knowledge before the Industrial Revolution (Case: Antwerp.)" Technology and Culture 51, no. 2 (2010): 332-56.

De Munck Bert, Steven L. Kaplan, and Hugo Soly, eds. Learning on the Shop Floor: Historical Perspectives on Apprenticeship. New York: Berghahn Books, 2007.

_ . "Gilding Golden Ages: Perspectives from Early Modern Antwerp on the Guild Debate, c. 1450-c. 1650." European Review of Economic History 15 (2011): 221-53.

Dunlop, O. Jocelyn. "Some Aspects of Early English Apprenticeship." Transactions of the Royal Historical Society, 3rd Series, 5 (1911): 193-208.

—. English Apprenticeship and Child Labor. New York: MacMillan, 1912.

Elbaum, Bernard. "Why Apprenticeship Persisted in Britain But Not in the United States." Journal of Economic History 49, no. 2 (1989): 337-49.

Elbaum, Bernard, and Singh, Nirvikar. "The Economic Rationale of Apprenticeship Training: Some Lessons from British and U.S. Experience." Industrial Relations: A Journal of Economy and Society 34, no. 4 (1995): 593-622.

Epstein, S. R. "Craft Guilds, Apprenticeship, and Technological Change in Preindustrial Europe.” Journal of Economic History 58, no. 3 (1998): 684-713.

- "Transferring Technical Knowledge and Innovating in Europe, c. 1200 c. 1800." In Technology, Skills and the Pre-Modern Economy in the East and the West, edited by Jan L. van Zanden and Maarten Prak. Boston: Brill, 2013.

Feldman, Naomi E., and Karine van der Beek. "Skill Choice and Skill Complementarity in Eighteenth Century England." Explorations in Economic History 59 (2016): 94-113.

Fitzsimmons, Michael P. From Artisan to Worker: Guilds, the French State and the Organization of Labor, 1776-1821. Cambridge: Cambridge University Press, 2010.

Gadd, Ian Anders, and Patrick Wallis. "Reaching Beyond the City Wall: London Guilds and National Regulation, 1500-1700." In Guilds, Innovation and the European Economy, 1400-1800, edited by S.R. Epstein and Maarten Prak, 288-315. Cambridge: Cambridge University Press, 2008.

Galor, Oded. Unified Growth Theory. Princeton, NJ: Princeton University Press, 2011.

Glaeser Edward L., Rafael La Porta, Florencio Lopez-de-Silanes, et al. "Do Institutions Cause Growth?” Journal of Economic Growth 9, no. 3 (2004): 271-303.

Griffiths, Trevor, Philip A. Hunt, and Patrick K. O'Brien. "Inventive Activity in the British Textile Industry, 1700-1800.” Journal of Economic History 52, no. 4 (1992): 881-906.

Hall, Peter. The Bootstrap and Edgeworth Expansion New York: Springer-Verlag, 1992.

Harris, John R. Industrial Espionage and Technology Transfer: Britain and France in the Eighteenth Century. Aldershot: Ashgate, 1998.

Harris, Ron. "Government and the Economy, 1688-1850." In The Cambridge Economic History of Modern Britain 1, edited by Roderick C. Floud and Paul Johnson, 204-37. Cambridge: Cambridge University Press, 2004. 


\section{Flexible Supply of Apprenticeship}

Henderson, W.O. Britain and Industrial Europe, 1750-1870; Studies in British Influence on the Industrial Revolution in Western Europe. Liverpool: Liverpool University Press, 1954.

Humphries, Jane. "English Apprenticeship: A Neglected Factor in the First Industrial Revolution." In The Economic Future in Historical Perspective, edited by Paul A. David and Mark Thomas. Oxford University Press, 2003.

- "Household Economy." In Cambridge Economic History of Modern Britain 1, 238-67. Cambridge: Cambridge University Press, 2004.

- Childhood and Child Labour in the British Industrial Revolution. Cambridge University Press: Cambridge Books Online, 2010.

Irigoyen, Claudio, Esteban Rossi-Hansberg, and Mark L. J. Wright. Solutions Manual for Recursive Methods in Economic Dynamics. Cambridge, MA: Harvard University Press, 2009.

Justman, Moshe, and Karine Van der Beek. "Market Forces Shaping Human Capital in Eighteenth Century London." Economic History Review 68, no. 4 (2014): $1177-202$.

Kaplan, Steven L. "l'Apprentissage à Paris au XVIIIe siècle: le cas de Paris." Revue d'Histoire Moderne et Contemporaine 40, no. 3 (1993): 436-79.

Kelly, Morgan, Joel Mokyr, and Cormac Ó Gráda. "Precocious Albion: A New Interpretation of the British Industrial Revolution." Annual Review of Economics 6 (2014): 363-91.

Lequin, Yves. “Apprenticeship in Nineteenth-Century France: A Continuing Tradition or a Break with the Past?" In Work in France, edited by Steven L. Kaplan and Cynthia J. Koepp, 457-74. Ithaca: Cornell University Press, 1986.

Leunig, Tim, Chris Minns, and Patrick Wallis. "Networks in the Premodern Economy: The Market for London Apprenticeships, 1600-1749." Journal of Economic History 71, no. 2 (2011): 413-41.

Lucas, Robert E., Jr. “Adjustment Costs and the Theory of Supply.” Journal of Political Economy 75, no. 4 (1967): 321-34.

McCloskey, Deirdre. Bourgeois Dignity: Why Economics Can't Explain the Modern World. Chicago: University of Chicago Press, 2010.

Meisenzahl, Ralf R., and Joel Mokyr. "The Rate and Direction of Invention in the British Industrial Revolution: Incentives and Institutions." In The Rate and Direction of Inventive Activity Revisited, edited by Joshua Lerner and Scott Stern, 443-79. Chicago: University of Chicago Press, 2011.

Minns, Chris, and Patrick Wallis. "The Price of Human Capital in a Pre-industrial Economy: Premiums and Apprenticeship Contracts in 18th Century England." Explorations in Economic History 50, no. 3 (2013): 335-50.

Mitch, David. "The Role of Education and Skill in the British Industrial Revolution." In The British Industrial Revolution: An Economic Perspective 2nd ed., edited by Joel Mokyr, 241-79. Boulder, CO: Westview Press, 1999.

- "Education and the Skill of the British Labor Force." In The Cambridge Economic History of Britain, 1700-2000, Vol. 1, edited by Roderick C. Floud and Paul Johnson, 332-56. Cambridge: Cambridge University Press, 2004.

Mokyr, Joel. "Editor's Introduction: The New Economic History and the Industrial Revolution." In The British Industrial Revolution: An Economic Perspective, 2nd ed., edited by Joel Mokyr, 1-127. Boulder, CO: Westview Press, 1999. 
- "The Institutional Origins of the Industrial Revolution." In Institutions and Economic Performance, edited by Elhanan Helpman, 64-119. Cambridge, MA: Harvard University Press, 2008.

- The Enlightened Economy: An Economic History of Britain, 1700-1850. New Haven, CT: Yale University Press, 2009.

Nuvolari, Alessandro, and Tartari Valentina. "Bennet Woodcroft and the Value of English Patents, 1617-1841.” Explorations in Economic History 48, no. 1 (2011): 97-115.

Ogilvie, Sheilagh. "The Economics of Guilds.” Journal of Economic Perspectives 28, no. 4 (2014): 169-92.

Pellegrin-Postel, Nicole. "Contrats d'Apprentisage en Haut-Poitou au XVIIIe Siècle." Bulletin de la Société des Antiquaires de l'Ouest et des Musées de Poitiers XVII (1987): 259-310.

Ryoo, Jaewoo, and Sherwin Rosen. "The Engineering Labor Market." Journal of Political Economy 112, no. 1 (2004): S110-40.

Sandberg, Lars G. "The Case of the Impoverished Sophisticate: Human Capital and Swedish Economic Growth before World War I." Journal of Economic History 39, no. 1 (1979): 225-41.

Schwarz L. D. London in the Age of Industrialization: Entrepreneurs, Labour Force and Living Conditions, 1700-1850. Cambridge: Cambridge University Press, 1992.

Steffens, Sven. "Le métier volé: Transmission des savoir-fair et socialization dans les métiers qualifiés ay XIXe siècle." Revue du Nord 15 (2001): 121-35.

Stokey, Nancy L., and Robert E. Lucas. Recursive Methods in Economic Dynamics. Cambridge, MA: Harvard University Press, 1989.

Van der Beek, Karine. "England's Eighteenth-Century Demand for High-Quality Workmanship: Evidence from Apprenticeship, 1710-1770." In Institutions, Innovation, and Industrialization: Essays in Economic History and Development, a festschrift volume in the honor of Prof. Joel Mokyr, edited by Lynne Kiesling and John V.C. Nye, 268-74. Princeton University Press, 2014.

Van Leeuwen, Marco H.D., Ineke Maas, and Andrew Miles. HISCO: Historical International Standard Classification of Occupations. Leuven: Leuven University Press, 2002.

Van Zanden, Jan Luiten. The Long Road to the Industrial Revolution. The European Economy in a Global Perspective, 1000-1800. Leiden: Brill, 2009.

Wallis, Patrick. "Apprenticeship and Training in Premodern England." Journal of Economic History 68, no. 3 (2008): 832-61.

Wrigley, E., and R. Schofield. The Population History of England 1541-1871: A Reconstruction. London, UK: Edward Arnold, 1981. 